Research Paper

\title{
Mutational re-modeling of di-aspartyl intramembrane proteases: uncoupling physiologically-relevant activities from those associated with Alzheimer's disease
}

\author{
Anastasia P. Grigorenko ${ }^{1,2,3, *}$, Youri K. Moliaka ${ }^{1, *}$, Olga V. Plotnikova ${ }^{1}$, Alexander \\ Smirnov $^{1}$, Vera A. Nikishina ${ }^{1}$, Andrey Y. Goltsov ${ }^{2,3}$, Fedor Gusev ${ }^{2,3}$, Tatiana V. \\ Andreeva ${ }^{2,3}$, Omar Nelson ${ }^{4}$, Ilya Bezprozvanny ${ }^{4}$ and Evgeny I. Rogaev ${ }^{1,2,3,5}$ \\ ${ }^{1}$ Department of Psychiatry, Brudnick Neuropsychiatric Research Institute, University of Massachusetts Medical School, \\ Worcester, MA 01604, USA \\ ${ }^{2}$ Department of Genomics and Human Genetics, Institute of General Genetics, Russian Academy of Sciences, Moscow, \\ 119991 Russia \\ ${ }^{3}$ Center for Brain Neurobiology and Neurogenetics, Institute of Cytology and Genetics, Siberian Branch of the Russian \\ Academy of Sciences, Novosibirsk, 630090, Russia \\ ${ }^{4}$ Department of Physiology, University of Texas Southwestern Medical Center at Dallas, Dallas, TX 75390-9040, USA \\ ${ }^{5}$ Center for Genetics and Genetic Technologies, Faculty of Biology, Faculty of Bioengineering and Bioinformatics, Lomonosov \\ Moscow State University, Moscow, 119234, Russia \\ *These authors have contributed equally to this work \\ Correspondence to: Anastasia P. Grigorenko, email: Anastasia.Grigorenko@umassmed.edu \\ Evgeny I. Rogaev, email: Evgeny.Rogaev@umassmed.edu \\ Keywords: regulated intramembrane proteolysis, intramembrane aspartyl proteases, presenilin, IMPAS/SPP, mutational re-modelling \\ Received: October 04, $2016 \quad$ Accepted: April 28, $2017 \quad$ Published: May 30, 2017 \\ Copyright: Grigorenko et al. This is an open-access article distributed under the terms of the Creative Commons Attribution License \\ 3.0 (CC BY 3.0), which permits unrestricted use, distribution, and reproduction in any medium, provided the original author and \\ source are credited.
}

\section{ABSTRACT}

The intramembrane proteolytic activities of presenilins (PSEN1/PS1 and PSEN2/ PS2) underlie production of $\beta$-amyloid, the key process in Alzheimer's disease (AD). Dysregulation of presenilin-mediated signaling is linked to cancers. Inhibition of the $Y$-cleavage activities of PSENs that produce $A \beta$, but not the $\varepsilon$-like cleavage activity that release physiologically essential transcription activators, is a potential approach for the development of rational therapies for AD. In order to identify whether different activities of PSEN1 can be dissociated, we designed multiple mutations in the evolutionary conserved sites of PSEN1. We tested them in vitro and in vivo assays and compared their activities with mutant isoforms of presenilin-related intramembrane di-aspartyl protease (IMPAS1 (IMP1)/signal peptide peptidase (SPP)). PSEN1 autocleavage was more resistant to the mutation remodeling than the $\varepsilon$-like proteolysis. PSEN1 with a G382A or a P433A mutation in evolutionary invariant sites retains functionally important APP $\varepsilon$ - and Notch S3- cleavage activities, but G382A inhibits $A P P$ Y-cleavage and $A \beta$ production and a P433A elevates $A \beta$. The $G 382 A$ variant cannot restore the normal cellular ER $\mathrm{Ca}^{2+}$ leak in PSEN1/PSEN2 double knockout cells, but efficiently rescues the loss-of-function (Egl) phenotype of presenilin in C. elegans. We found that, unlike in PSEN1 knockout cells, endoplasmic reticulum (ER) $\mathrm{Ca}^{2+}$ leak is not changed in the absence of IMP1/SPP. IMP1/SPP with the analogous mutations retained efficiency in cleavage of transmembrane substrates and rescued the lethality of Ce-imp-2 knockouts. In summary, our data show that mutations near the active catalytic sites of intramembrane di-aspartyl proteases have different consequences on proteolytic and signaling functions. 


\section{INTRODUCTION}

Presenilins (termed PS1 and PS2 or PSEN1 and PSEN2 [1, 2]) are homologous di-aspartyl proteases, capable of cleaving various type I transmembrane proteins within their intramembrane domains. Mutations in PSEN1 and PSEN2 are major causative genetic factors of familial cases of Alzheimer's disease (AD), characterized by early onset $\mathrm{AD}$ manifestation $[1,2]$. PSEN1 or PSEN2 intramembranous and BACE1 extracellular cleavages of amyloid precursor protein (APP), produce short 40-, 42- amino acid $\beta$-amyloid peptides (A $\beta$ ). AD autosomal dominant missense mutations in the presenilins have been reported to increase $A \beta$ production and the ratio of $A \beta 42 / 40$ peptides [3]. PSEN cleavage releases the intracellular domains (ICD) of type I proteins that can act as intracellular signaling molecules, activating gene transcription (e.g., Notch-signaling genes) (reviewed in [3]). Presenilins function as components of the multipleprotein $\gamma$-secretase complex and have evolutionarily invariant amino acid signatures around two conserved catalytic aspartates and a PAL-motif (human PSEN1 D257, D385, PAL433-435) (Figure 1A, Supplementary Figure 1) [4-11]. There are three major proteolytic activities associated with presenilins: (i) "presenilinase"PSEN autocleavage, (ii) intramembrane $\gamma$-cleavage leading to generation of $A \beta$ peptides and (iii) juxtamembrane $\varepsilon$-cleavages of APP, Notch 1 and other type I protein substrates resulting in release of ICDs - intracellular transcriptional regulators (Supplementary Figure 2) Active $\gamma$-secretase complex requires four proteins: Nicastrin, PEN2, APH1 and PSEN [12, reviewed in 13, 14]. Although various missense mutations in PSEN1 lead to autosomal-dominant AD (summarized in AlzForum Mutation Database), heterozygous loss-of-function mutations in PSEN1 as well as in Nicastrin and PEN2 (haploinsufficiency) have been shown to cause specific severe inflammatory skin disease, termed acne inversa in humans [15], reviewed in [16]. Clinical trials of drugs for $\mathrm{AD}$ inhibiting $\gamma$-secretase activity revealed various effects on skin, including a higher risk of skin cancer $[16,17]$. In mice, loss of PSEN1 causes skin cancer, and a reduction of PSENs function is responsible for myeloproliferative disease $[18,19]$. An inverse association between AD and cancer has been proposed with multiple regulatory mechanisms, including Pin1-, p53-, Wnt-related signaling, proposed to underlie the diseases [20, 21, reviewed in 22]. Among the important presenilin functions is regulation of Wnt signaling/ $\beta$-catenin phosphorylation and turnover, which can contribute to skin cancer [18, 23-25]. This regulation can occur indirectly via cadherins as described in [26]. Another reported property of PSEN1 is its activity as a low conductance endoplasmic reticulum (ER) $\mathrm{Ca}^{2+}$ leak channel with a regulatory role in pathways linked to intracellular $\mathrm{Ca}^{2+}$ homeostasis [27-30]. Numerous studies have shown the involvement of PSEN1 in the autophagylysosome degradative pathway, which is also a function independent of $\gamma$-secretase proteolysis [31-34]. Since both the up- and down-regulation of presenilins and presenilinmediated signaling pathways, in particular Notch, may lead to various cancers $[18,35-41]$, the balanced physiological level of presenilin/ $\gamma$-secretase activity is essential for normal biological function. Therefore, the direct approach for down-regulation of $\gamma$-secretase by $\gamma$-secretase inhibitors for reduction of $A \beta$ generation may not be appropriate for $\mathrm{AD}$ treatment. On the other hand, suppression or modification of proteolytic activity producing $A \beta$ with retained physiological activity of presenilin is an attractive strategy in $\mathrm{AD}$ therapy.

The gene family for polytopic proteins termed intramembrane di-aspartyl proteases (IMPAS) or signal peptide proteases (SPP) includes the five known paralogous genes, designated as IMP1, $-2,-3,-4,-5$; or $S P P, S P P L 2 a,-2 b,-2 c,-3$; or $P S H$ gene family [42-44]. These proteins were described as structural homologs of presenilins, registered in MEROPS database as peptidase subfamily A22B [45]. PSEN and IMP1/SPP proteases share identical evolutionarily conserved motifs for the catalytic sites YD and GxGD and the PAL domain in their C-termini (Figure 1) [4-7, 42]. Unlike PSEN1 and PSEN2, which cleave type I transmembrane proteins, IMP1/SPP proteins cleave type II transmembrane substrates with the N-terminus oriented to the cytosol [43, 46, 47]. Some potent $\gamma$-secretase inhibitors can efficiently work for IMP1/SPP [46]. In our previous work, we showed that human hIMP1/SPP can cleave polytopic PSEN1 protein within its membrane domain in vitro [47]. In another independent study, a signal peptide peptidase (SPP) that regulates the cleavage of specific short signal peptides in the ER was isolated [43]. The major hIMP1 isoform is identical to human SPP encoded by the same gene and orthologous to C. elegans Ce-imp-2 gene [42, 43, 47]. We identified a phenotype caused by inactivation of the Caenorhabditis elegans hIMP1/SPP orthologue, $\mathrm{Ce}$ imp-2, possibly related to a cholesterol-dependent cellular pathway [48]. In vitro assays demonstrated that hIMP1/ SPP cleaves short signal peptide remnants tethered in ER membranes. This activity may generate short signal sequences that are essential for HLA-E epitopes [43, 49]. This protease also participates in processing of the hepatitis $\mathrm{C}$ core protein (HCV core protein, [50], ERresident tail-anchored proteins, the unfolded protein response (UPR regulator XBP1u and other proteins (data is summarized in Supplementary Figure 3).

Modulating the different activities of PSEN and IMP1/SPP-related di-aspartyl intramembrane proteases is important for a better understanding of their functions and is essential for studies aimed at dissociating their proteolytic properties. Here we created a series of constructs bearing mutations focused upon (i) the highly conserved signature GLGD; (ii) the PAL- motif that is evolutionarily invariant in both the PSEN and IMP1/ SPP protein families; and (iii) AD mutation positions of PSEN1 (Figure 1). Various mutations in the same 
A
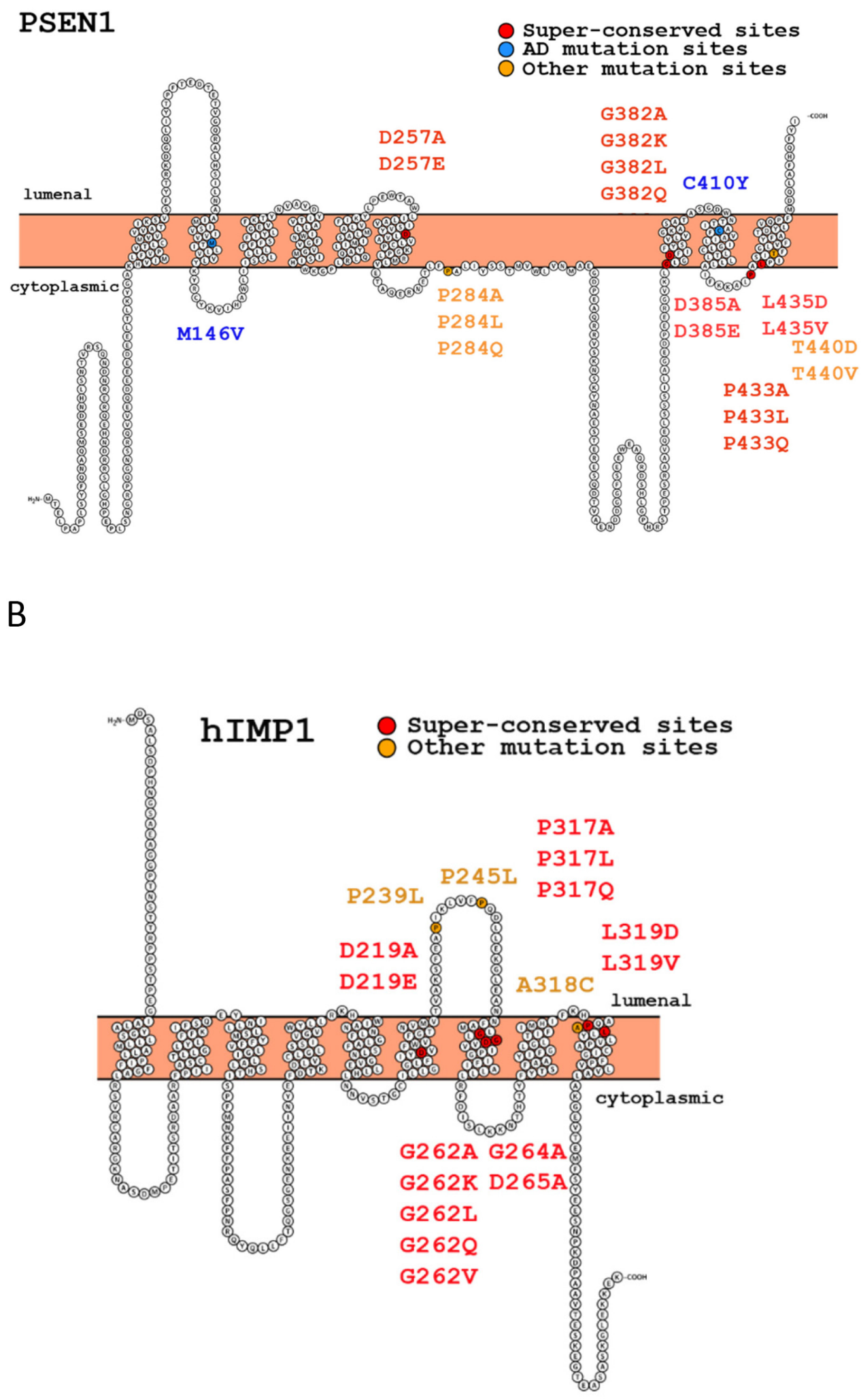

Figure 1: Structures of human presenilin 1 (PSEN1) and IMP1 (hIMP1) proteins and mutations used in the study (Protter program visualization, http://wlab.ethz.ch/protter). 
amino acid positions were incorporated to generate subtle or radical alterations of hydrophobicity of the sites [51-53] (Supplementary Tables 1 and 2). We tested how the designed mutations affect the processing and functional properties of PSEN1 enzyme in intramembrane proteolysis assays comparing to similar mutations in the hIMP1/SPP protease (preliminary data were reported in [54]). In addition, for selected mutations, we performed rescue experiments in a transgenic $C$. elegans. To test the effects of the mutations on non-proteolytic functions of PSEN1 and whether IMP1/SPP possess such functions, we employed $\mathrm{ER} \mathrm{Ca}^{2+}$ leak assays using mouse embryonic fibroblasts deficient in the PSEN or IMP1/SPP genes.

\section{RESULTS}

\section{Proteolytic properties of PSEN1}

\section{(1) Presenilinase auto-cleavage}

Presenilin proteins undergo several post-translation modifications including endoproteolysis of full length protein (FL PSEN) by "presenilinase" within the seventh hydrophobic domain leading to accumulation of 27-28
kDa N-terminal (NTF) and 16-17 kDa C-terminal (CTF) products [55]. "Presenilinase" is likely to be the presenilin per se undergoing autoprocessing in the cis-position that has aspartyl protease activity distinct from $\gamma$-secretase biochemical properties. The proteolytic event takes place mainly in ER compartments and requires at last one other $\gamma$-secretase complex component, PEN2 protein [56-60]. Mutations in conserved aspartates of PSEN1 are critical for both presenilinase and $\gamma$-secretase activities. Overexpression of NTF or CTF fragments bearing mutations at catalytic aspartate sites cannot restore the $\gamma$-secretase activity in C. elegans mutants [61]. Mutations in the "presenilinase" cleavage site (PSEN1 M292D, M292E) strongly inhibit the autocleavage while the AD-related PSEN1 $\triangle \mathrm{E} 9$ mutation completely abolishes PSEN1 endoproteolysis, although in both cases $\gamma$-secretase remains active $[59,62]$. Variable inhibitory effects on PSEN1 processing have been described for different AD-associated mutations [63-65].

We transfected PSEN1 $^{-/} /$PSEN2 ${ }^{-/}$mouse embryonic fibroblasts (MEF) cells with wild type or mutant PSEN1 constructs and examined PSEN1 auto-cleavage products via immunoblotting using PSEN1 N-terminal antibody (Figure 2). We confirmed previous findings
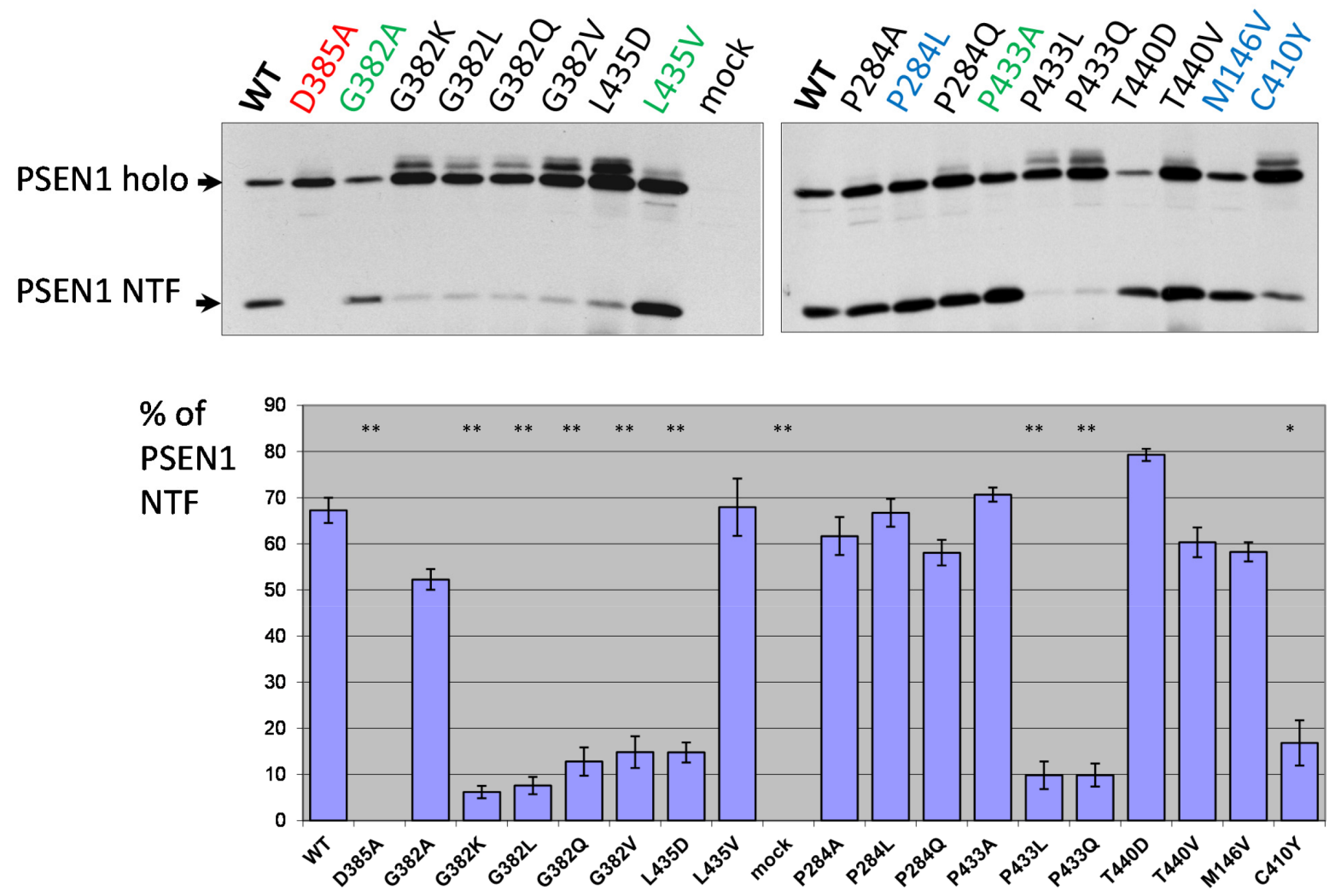

Figure 2: Study of PSEN1 mutants in presenilinase cleavage assay. The cleavage product was detected by PSEN1 N-terminal antibody. Transfections were performed in $P S E N 1^{-/} / P_{S E N 2}{ }^{-/}$MEF cells. Histogram shows the percent ratio of PSEN1 NTF to uncleaved PSEN1 holoprotein. Error bars represent SE. In this and all other Figures, mutations in super-conserved aspartates are indicated in red, mutations with similar amino acid changes, which do not alter the physicochemical properties of the site, are in green and AD mutations are in blue. P-value significance codes: '**' $<0.01$, '*' $<0.05$. 
$[4,6]$ that mutations in specific aspartate residues of PSEN1 (D257A, D257E, D385A, D385E) completely abolish PSEN holoprotein cleavage as well as $\gamma$-secretase activity. We used cells over-expressing PSEN1 D385A as a dominant-negative control in all proteolytic assays. Our data on the effects of PSEN1 mutations indicate that mutations that critically change physicochemical properties (hydrophobicity) of the ultra-conserved amino acids G382, P433 and L435, strongly inhibit, but not completely abolish, the presenilinase activity. Similar amino acid substitutions G382A, P433A and L435V in the evolutionary conserved sites had much less or no effect on PSEN1 processing (Figure 2, Supplementary Table 1). We observed similar weak inhibitory effects of the various mutations in less conserved and AD-related amino acid positions (Figure 2). As previously described, $\mathrm{AD}$-associated $\mathrm{C} 410 \mathrm{Y}$ mutation led to a strong inhibition of PSEN1 processing (Figure 2) [64, 65].

\section{(2) Notch1 $\triangle E$ cleavage by PSEN1}

Among the major PSEN substrates is a Notch family of proteins, which mediate important signaling pathways in the development and function of multicellular organisms [66]. PSEN1 has been shown to cleave $\mathrm{NH}^{2}$ terminally-truncated Notch derivates $(\operatorname{Notch} \Delta \mathrm{E})$ within their intramembrane domains ( $\varepsilon$ - or S3-cleavage) and to release the Notch intracellular domain (NICD), which functions as a transcriptional activator[67-70].

We co-transfected Notch $1 \triangle \mathrm{E}$ along with different PSEN1 mutant constructs in PSEN1 $1 /$ PSEN2 ${ }^{-/}$MEF cells and studied the cleavage products in cell-free membrane assays (see Material and Methods). Consistent with the data from the "presenilinase" cleavage assays, mutations in highly conserved amino acids G382, P433 and L435, which affect the physicochemical properties of the protein, completely suppress Notch $1 \Delta \mathrm{E} \varepsilon$-cleavage, whereas mutations G382A, P433A and L435V had a less inhibitory effect (Figure 3). Among other mutations, including ADlike mutations, only $\mathrm{C} 410 \mathrm{Y}$ substitution abolished or strongly inhibited Notch1 processing (Figure 3).

\section{(3) Production of carboxy-terminal fragments and $A \beta$ peptides by APP processing}

Another important type I protein proteolytically processed by presenilins is APP. Extramembrane endoproteolysis of APP by BACE produces the 99-amino acid $\mathrm{C}$-terminus fragment anchored in the membrane. This $\mathrm{C}$-terminus fragment is the substrate for $\gamma$-secretase cleavage. We used the transgenic construct APP695 isoform (APP695 $\Delta \mathrm{NL}$ ) that bears the Swedish mutation for $\mathrm{AD}(\mathrm{KM} 670 / 671 \mathrm{NL})$, and enhances the overall production of $A \beta$ [71-73] (Supplementary Figure 2C) for co-expression with the mutant PSEN1 constructs in $P S E N 1^{-1} / P S E N 2^{-} \mathrm{MEF}$ cells. Mutations in PSEN genes are responsible for changes in intramembrane $\gamma$-proteolysis events, resulting in accumulation of the amyloidogenic product $(\mathrm{A} \beta 40, \mathrm{~A} \beta 42)$ that is the major component of amyloid senile plaques in $\mathrm{AD}$ [74-76, reviewed in 3]. After shedding of the extracellular N-terminal part of APP, cleavage in the APP $\varepsilon$-site by $\gamma$-secretase complex generates the carboxy-terminal amyloid intracellular domain (AICD) [77]. AICD, similar to NICD, can regulate transcription of various genes, including the genes encoding EGFR, a protein tyrosine kinase up-regulated in tumors. Reduction of PSEN1 activity can regulate EGFRmediated tumorogenesis [78]. PSEN1 mutants P284A/ L/Q, G382A, L435V, P433A, T440V/D, transfected into

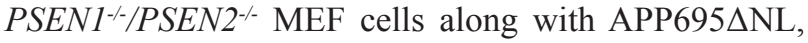
retain their proteolytic capacity to produce AICD showing various inhibitory or no inhibitory effects (Figure 4). No APP $\varepsilon$-proteolysis products were detected when D257A/E, D385A/E, G382K/L/Q/V, P433L/Q PSEN1 mutants were transfected into the PSEN1/PSEN2 double knockout cells. A strong inhibitory effect on APP $\varepsilon$-cleavage was demonstrated for mutation in evolutionary conserved site, L435D, and for AD mutation C410Y (Figure 4).

For the mutations in PSEN1 highly conservative sites, we also analyzed the A $\beta$-peptide profiles. A spectrum of A $\beta$ peptides were immunoprecipitated from PSEN1 $1^{-1-}$ IPSEN2 ${ }^{-}$MEF cells co-transfected with wild type or mutant PSEN1 and APP695 $\triangle$ NL constructs. We showed that PSEN1 P433A, that retains Notch1 S3- and APP $\varepsilon$-cleavage activities, is also active in APP $\gamma$-site cleavage generating elevated level of $A \beta$ peptides. In contrast, for the PSEN1 G382A that shows Notch1 S3- and APP $\varepsilon$-cleavage efficacy, we observed a strong inhibition of $A \beta 40$ and other $A \beta$ derivates (Figure 5). PSEN1 D385A, G382L, P433L mutations lead to complete inhibition of A $\beta$-peptide production compared to wild type PSEN1. The weak intensity low band suggesting the specific $A \beta$ fragment that differs from 1-42 was also observed in assays for PSEN1 G382A using high-resolution SDS-UREA-PAGE electrophoresis. This band was not observed using any other mutant constructs (Figure 5, Supplementary Figure 4).

\section{Proteolytic properties of IMP1/SPP}

\section{(1) Presenilin substrate cleavage}

Our previous experiments, in which we coexpressed PSEN1 holoprotein and human hIMP1/SPP in cultured cells, revealed that hIMP1/SPP is capable of cleaving a multipass transmembrane PSEN1 protein substrate [47]. We provided evidence that hIMP1/SPP may induce intramembrane proteolysis of PSEN1 in its last hydrophobic domain [47]. The significance of such cleavage activity in vivo has yet to be elucidated but a straightforward immunodetection assay has been developed to monitor proteolytic activity of IMP1 isoforms [47].

In the present study we co-transfected different IMP1/SPP mutant forms with PSEN1 substrate in HEK293 cells. Substitution mutations to structurally 

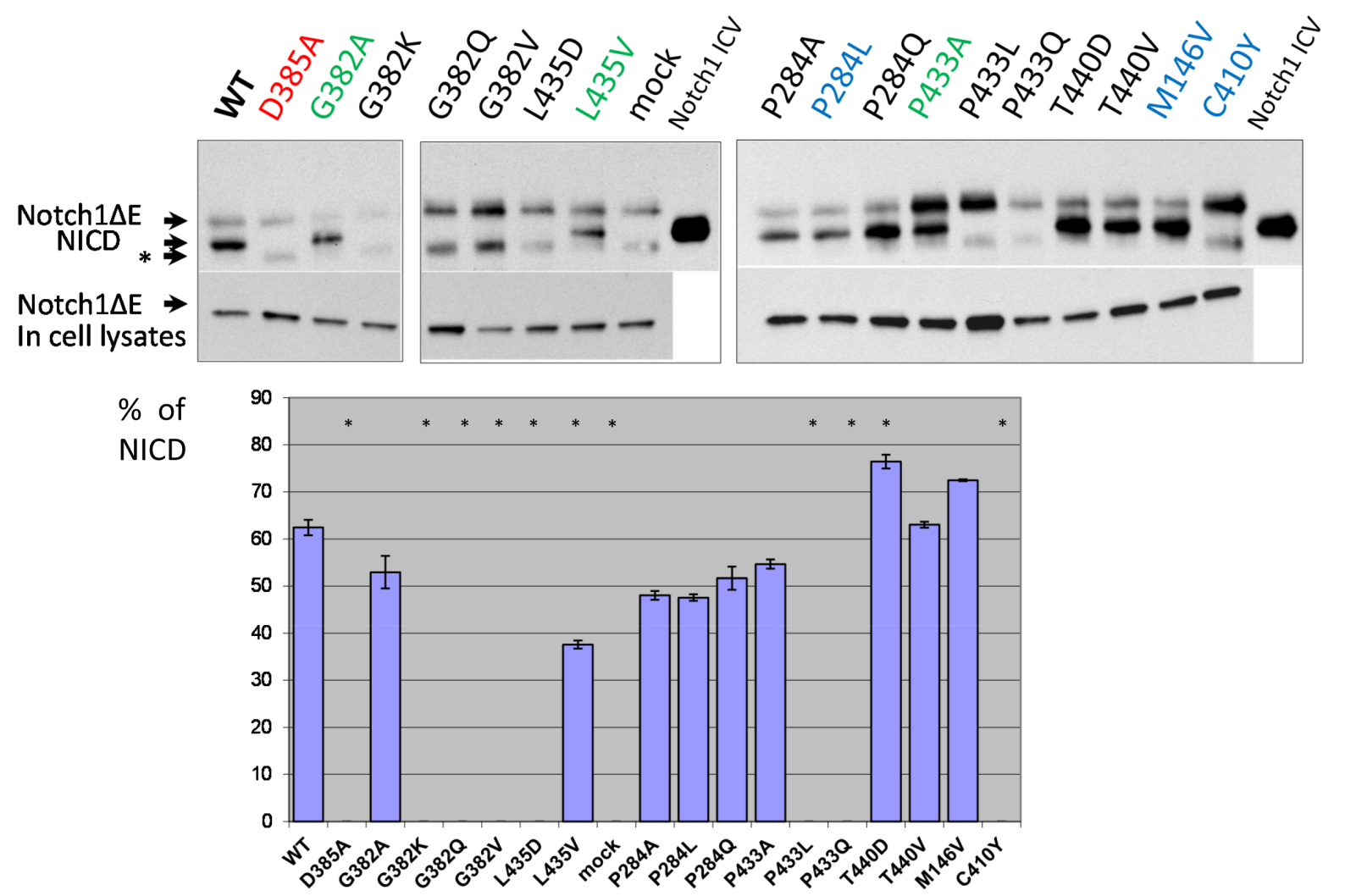

Figure 3: Study of PSEN1 mutants in Notch1 proteolytic assay. Co-transfections of wild type or mutant PSEN1 and Notch $\triangle E$ constructs were performed in PSEN1 ${ }^{-/} / P S E N 2^{-/}$MEF cells. Cleavage products were detected by C-myc antibody. Histogram shows the percent ratio of NICD to uncleaved Notch $\triangle \mathrm{E}$. An additional nonspecific band is marked by an asterisk. P-value significance codes: '*' $<0.05$.

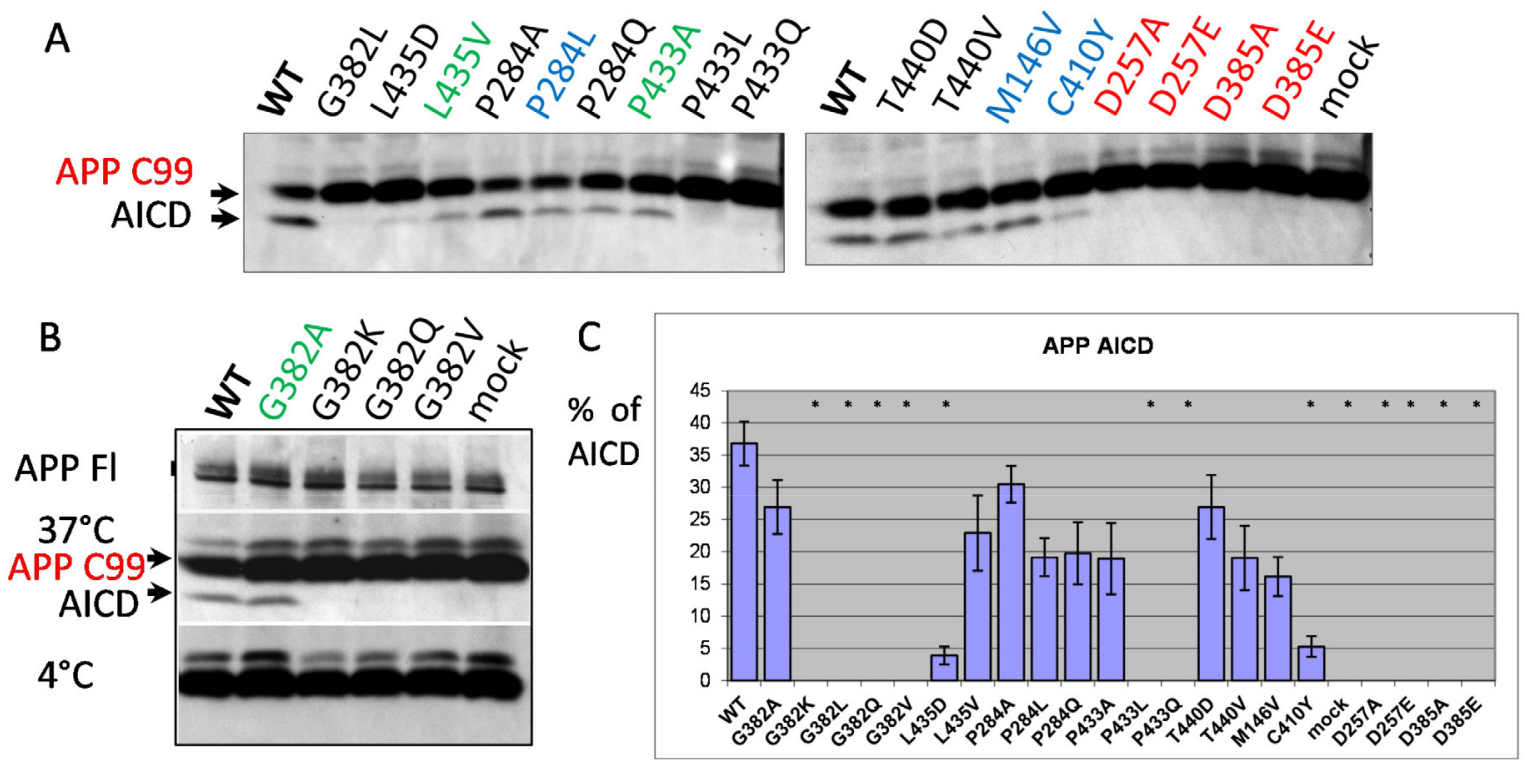

Figure 4: Study of PSEN1 mutants in APP \&-cleavage assay. (A, B) Co-transfections of wild type or mutant PSEN1 and APP695 bearing the Swedish mutation $(\triangle \mathrm{NL})$ were performed in $P S E N 1^{-/ / P S E N 2}{ }^{-/}$MEF cells. Cell-free intramembrane cleavage was induced by incubation of the samples at $37^{\circ} \mathrm{C}$ for 2 hours. APP C99 and $\gamma$-secretase cleavage product AICD were detected by APP CTF antibody (Sigma). No cleavage was observed for the control samples incubated on ice (B). mAb 22C11 antibody, which detects the full-length APP (APP FL), was used as a transfection control in the assay (B). (C) Histogram shows the percent ratio of AICD to uncleaved APP C99. P-value significance codes: ' $*$ ' $<0.05$. 
similar amino acids (such as G262A, G264A, P317A and L319V) lead to more efficient rescue capacities than mutations to structurally more distant amino acids in the same positions of hIMP1/SPP (Figure 6, Supplementary Table 2). Any changes in catalytic aspartate residues and distant mutations in evolutionarily conserved sites (e.g. G262K, P317L/Q, L319D) completely or nearly completely inhibited the proteolysis of PSEN1 substrate. The G262L mutation reduced the cleavage of PSEN1 by approximately $40 \%$. We have also shown that Ce-IMP-2, which is the C. elegans orthologue of human IMP1/SPP, can also cleave the $\mathrm{C}$-terminal domain of human PSEN1 with even higher efficacy than hIMP1/SPP (Figure 7 and below for more details).

\section{(2) HCV substrate cleavage}

We next examined how wild type and mutant hIMP1/SPP cleave an HCV (hepatitis $\mathrm{C}$ virus) substrate (Figure 8). hIMP1/SPP is known to cleave the immature form of $\mathrm{HCV}$ core protein in the hydrophobic transmembrane/C-terminal domain and this feature has become incorporated into a commonly used assay to study proteolytic properties of IMP1/SPP [50, 79]. The resulting cleavage product, p21 protein, along with the envelope proteins E1 and E2, are important structural components of the virus capsid [50, 80, 81]. Here we cotransfected FLAG-tagged HCV core protein along with different hIMP1/SPPs and detected the cleavage products in HEK293 cells (Figure 8). There is a strong inhibition of HCV core protein cleavage by hIMP1/SPP mutations D265A, P317L, G262V, and to a lesser extent, by G262L and G262A (Figure 8). Interestingly, hIMP1 G264A and hIMP1 A318C demonstrated high proteolytic activity in the HCV cleavage assay.

\section{Low conductance ER Ca ${ }^{2+}$ leak assay}

In addition to the protease function, presenilins may function as low conductance ion channels [27, 28]. Planar lipid bilayer reconstruction techniques showed that wild type presenilin 1 can form a $\mathrm{Ca}^{2+}$-permeable ion channel in the ER. Interestingly, mutations in the PSEN1 catalytic aspartate D257A, which is essential for PSEN1 proteolytic function, does not disrupt ion currents; whereas the AD mutation PSEN1 M146V impaired the channel function in a dominant negative manner [27]. The critical

\section{A}

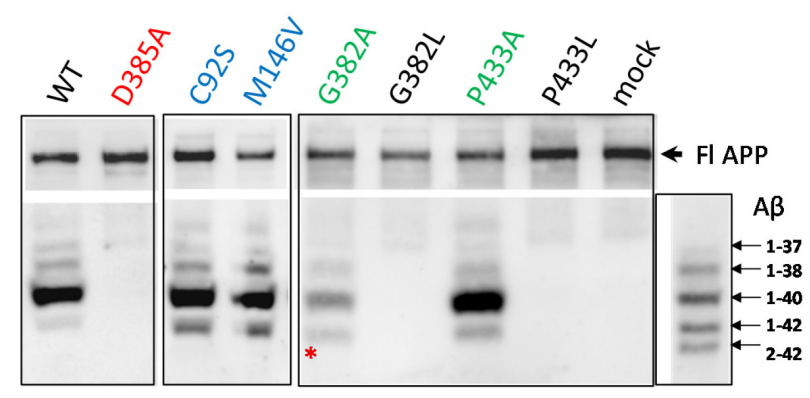

C

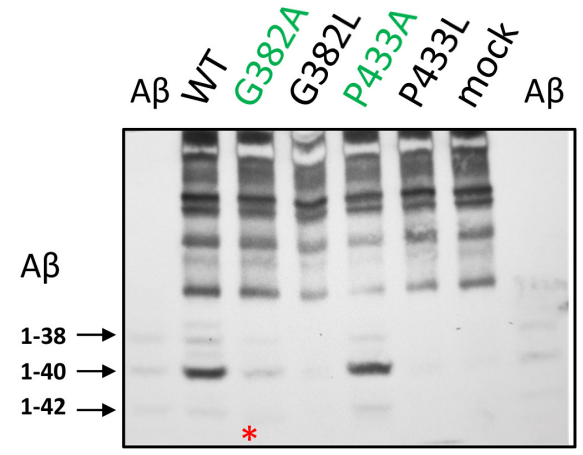

B

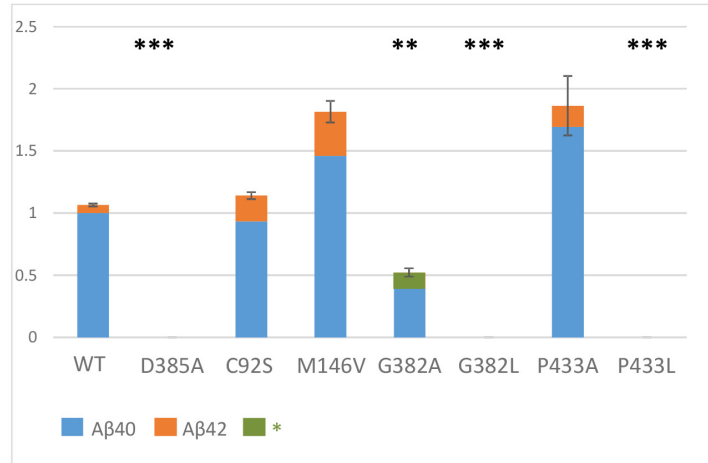

D

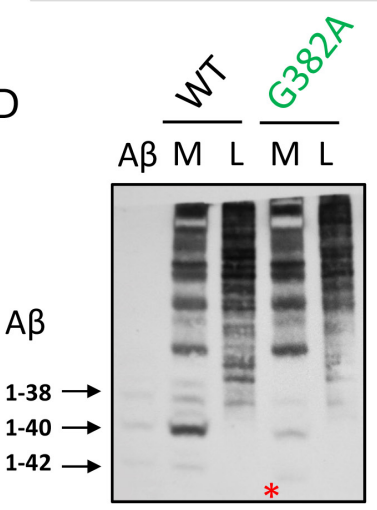

Figure 5: Detection of secreted A $\beta$ peptides in cell culture medium in $P S E N 1^{-/} / P S E N 2^{-/-}$MEF cells co-transfected with wild type or mutant PSEN1 and APP695 NL. Immunoprecipitation of secreted A $\beta$ in cell conditioned medium (A, C, D) and cell lysates (D). Immunoprecipitated $A \beta$ peptides were detected by $1 \mathrm{E} 8$ antibody. A $\beta$ - $\beta$-amyloid ladder. $\mathrm{M}$ - conditioned medium, L - cell lysate. * - a specific A $\beta$ peptide product, which differs from A $\beta 42$, was detected for the G382A construct. (B) Histogram shows the relative ratio of total amyloid (A $\beta 40$ and $A \beta 42$ or * $A \beta$ peptide product) in PSEN1 variants calibrated to wild type $A \beta 40$ level in 2-4 experiments. P-value significance codes: ' $* * *$ ' $<0.001$, '**' $<0.01$. AD mutations $\mathrm{C} 92 \mathrm{~S}$ and $\mathrm{M} 146 \mathrm{~V}$ were used as positive controls for $\mathrm{A} \beta 42$ product. 
pore structural positions were mapped to the PSEN1 hydrophobic domains 7 and 9 [28].

We next tested whether the mutations in glycine at position 382 (G382) that show variable effects on the proteolytic activities of PSEN1 and located in transmembrane domain 7 affect the cellular ER $\mathrm{Ca}^{2+}$ leak in PSEN1 and PSEN2 double-knockout MEFs. In a series of experiments, we observed that all tested mutations in glycine in position 382, including the G382A, which retains the $\gamma$-secretase activity, were unable to reconstitute the normal ER $\mathrm{Ca}^{2+}$ leak. In contrast, PSEN1 mutants with substitutions in proline 433 (P433A, P433L) restore the $\mathrm{Ca}^{2+}$ leak function in PSEN1 $1^{--} / P S E N 2^{-/-}$double-knockout cells similar to wild type PSEN1 function (Figure 9).

PSEN1 and IMP1/SPP are structurally related multipass proteins which cleave transmembrane domains
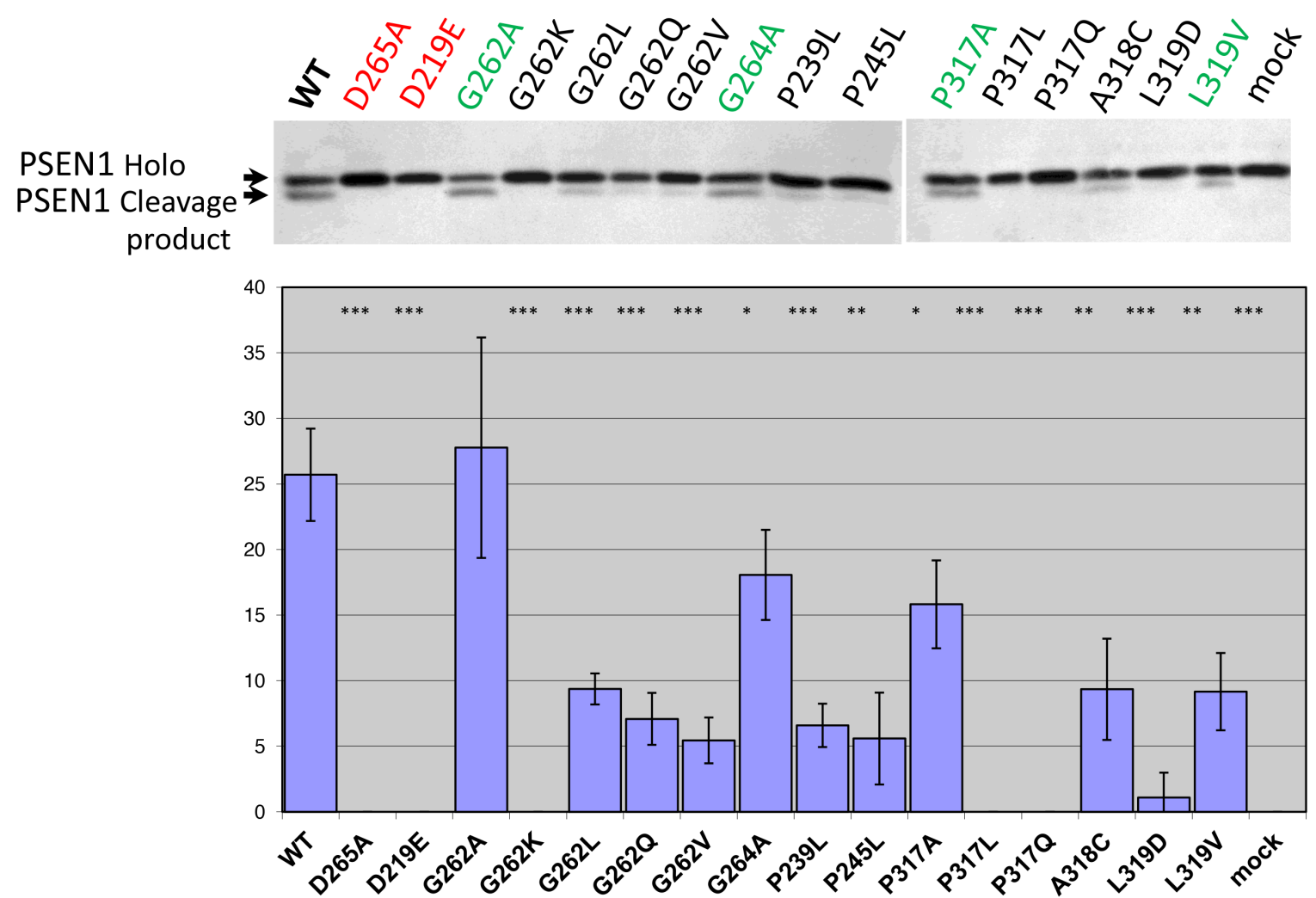

Figure 6: Study of hIMP1 mutants proteolytic cleavage of presenilin substrate. Co-transfections of wild type or mutant hIMP1 and PSEN1 constructs were performed in HEK293 cells. Histogram shows the percent ratio of cleaved PSEN1 to uncleaved PSEN1 holoprotein, detected with N-terminal hPSEN1. P-value significance codes: '***' $<0.001$, ' $* *$ ' $<0.01,{ }^{\text {' }}$ ' $<0.05$.

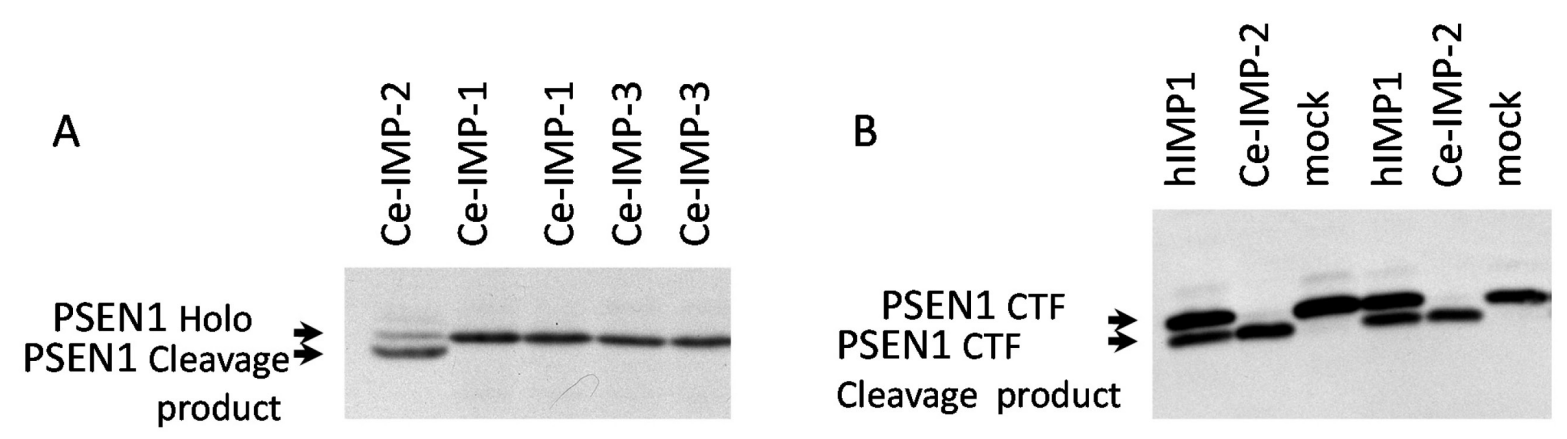

Figure 7: Ce-IMP-2 protein is efficiently cleaving hPSEN1 substrates. (A) Co-transfections of wild type $C$. elegans IMPAS and human PSEN1 constructs performed in HEK293 cells. Ce-IMP-2 protein, which is an orthologue of human IMP1, but not Ce-IMP-1 or Ce-IMP-3, is capable of cleaving hPSEN1 holoprotein, detected with N-terminal hPSEN1 antibody. (B) Co-expression of hPSEN1 CTF and hIMP1 or Ce-IMP-2 protein in PSEN1 ${ }^{-/}, P S E N 2^{-/}$double knockout fibroblasts. Efficient cleavage of hPSEN1 C-terminal fragment by Ce-IMP-2, with higher efficiency than by human IMP1 was detected by antibody for an N-terminal epitope of hPSEN1 CTF. 
of Type I and Type II proteins with opposite orientations $[3,43]$ (Figure 1). Whether the IMP1/SPP can also function as $\mathrm{Ca}^{2+}$ channels has never been studied. We addressed this question using cultured $m I M P 1 / S P P^{-}$ MEFs obtained from mIMP1/SPP knockout mice that were generated in our laboratory (unpublished). We tested the $\mathrm{Ca}^{2+}$ flow in mIMP1/SPP ${ }^{-/-}$and wild type $\mathrm{mIMP} 1 / \mathrm{SPP}^{+/+}$ MEF cells in comparison to PSEN1 ${ }^{-/} / P_{S E N 2}{ }^{-/}$and wild type PSEN1 ${ }^{+/+}$MEF cells. In contrast to PSEN1 knockout cells, the absence of IMP1/SPP protein does not affect the ER $\mathrm{Ca}^{2+}$ leak function, indicating that IMP1/SPP is not a $\mathrm{Ca}^{2+}$ pore (Figure 10).

\section{In vivo rescue experiments in $C$. elegans}

C. elegans is a popular and useful model organism for understanding the conserved mechanisms of ADrelated presenilin $/ \gamma$-secretase function and in identifying the components of the $\gamma$-secretase and signaling pathways regulated by presenilins [82]. Presenilin regulation of $\mathrm{Ca}^{2+}$ channel activities, similar to mammals, has been recently demonstrated in C. elegans [30].

In the present study, we examined the in vivo effect of the mutation in PSEN1 (G382A) that does not suppress the $\varepsilon$-proteolytic activity, but inhibits the $\gamma$-secretase proteolytic and $\mathrm{Ca}^{2+}$ channel activities of PSEN1. We generated a $C$. elegans presenilin sel-12 gene construct carrying a G361A mutation that corresponds to human PSEN1 position G382. We tested whether this mutant gene construct rescues the egg-lying defect (Egl) phenotype of sel-12(ar171)unc-1 C. elegans mutant, which has a premature stop codon and inactive Sel-12/presenilin protein [83]. We found that sel-12 G361A, as well as sel12 wild type transgene expression can efficiently rescue the egg-lying defect (Figure 11). Li and Greenwald have described that reduction of the activity of another $C$. elegans presenilin homolog, hop-1, can cause lethality in sel-12 mutant background strains [84]. Dead embryos/ arrested larvae phenotypes are associated in general with a reduction of lin-12/glp-1 Notch gene function, but does

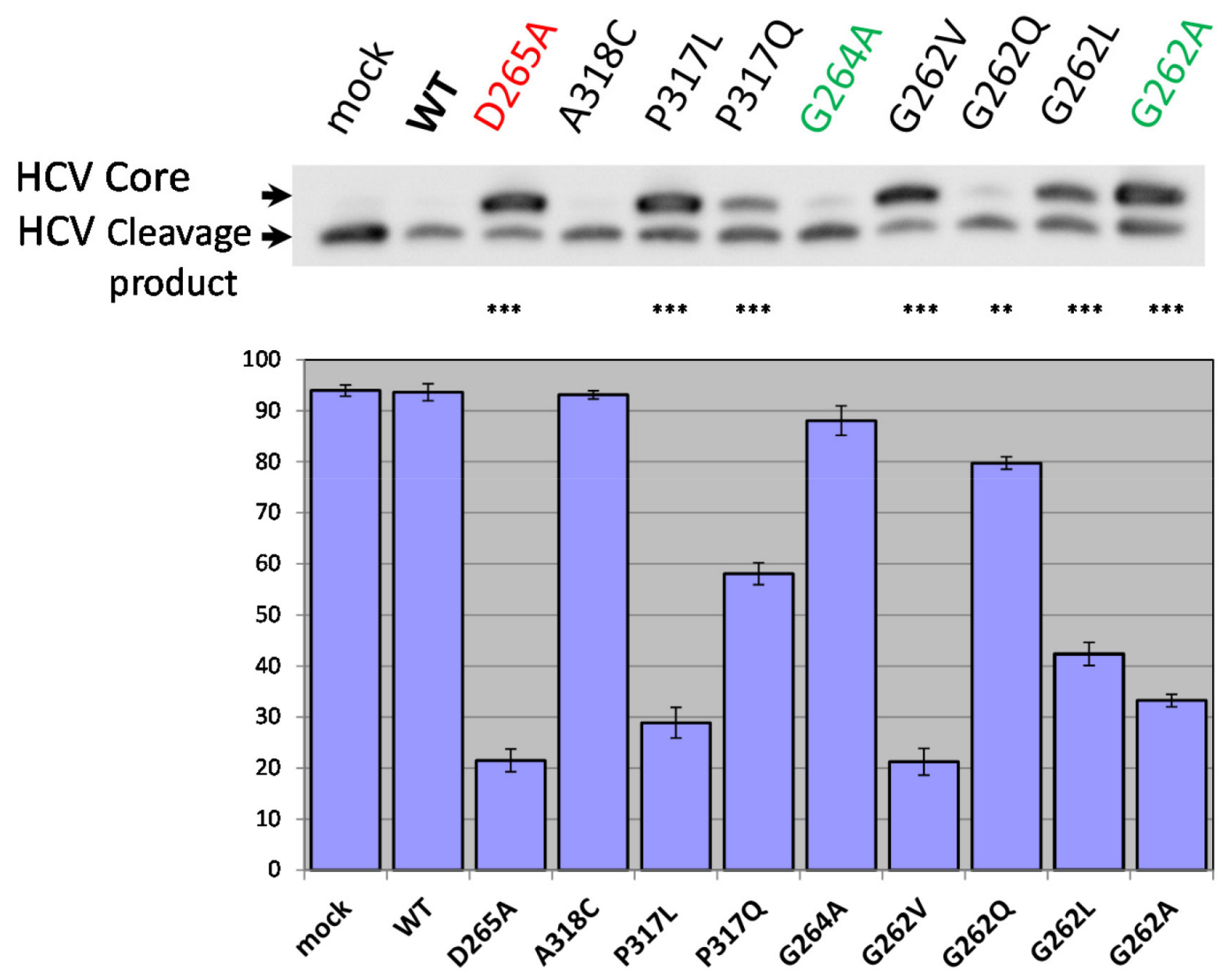

Figure 8: HCV cleavage assay. Co-transfections of wild type or mutant hIMP1 and HCV constructs were performed in HEK293 cells. Histogram shows the percent ratio of cleaved HCV to uncleaved HCV core protein, detected by anti-FLAG antibody. P-value significance codes: ' $* * *$ ' $<0.001$, ' $* *$ ' $<0.01$. 
not exclude the influence of other signaling pathways [84]. In our experiments, sel-12 G361A and sel-12 wild type strains, but not sur-5 GFP controls, can successfully survive for multiple generations being fed by hop-1 $R N A i$ bacteria, proving the rescue effect of sel-12 G361A in C. elegans when both presenilin homologues are suppressed (data not shown). All together, the data demonstrate that $\varepsilon$-proteolytic activity, but not the $\mathrm{Ca}^{2+}$ channel leak function, is essential for biological functions of presenilin, at least in early development and Notch-signaling.

We described previously three genes in C. elegans (Ce-imp-1, Ce-imp-2, Ce-imp-3) that are homologous to five paralogous human genes (IMP1/SPP and IMP-2, -3, $-4,-5)[42,48]$. Based on amino acid sequence alignments of these genes, we predicted that human hIMP1/SPP and

\section{$5 \mu \mathrm{M}$ ionomycin $(\mathrm{IO})$}

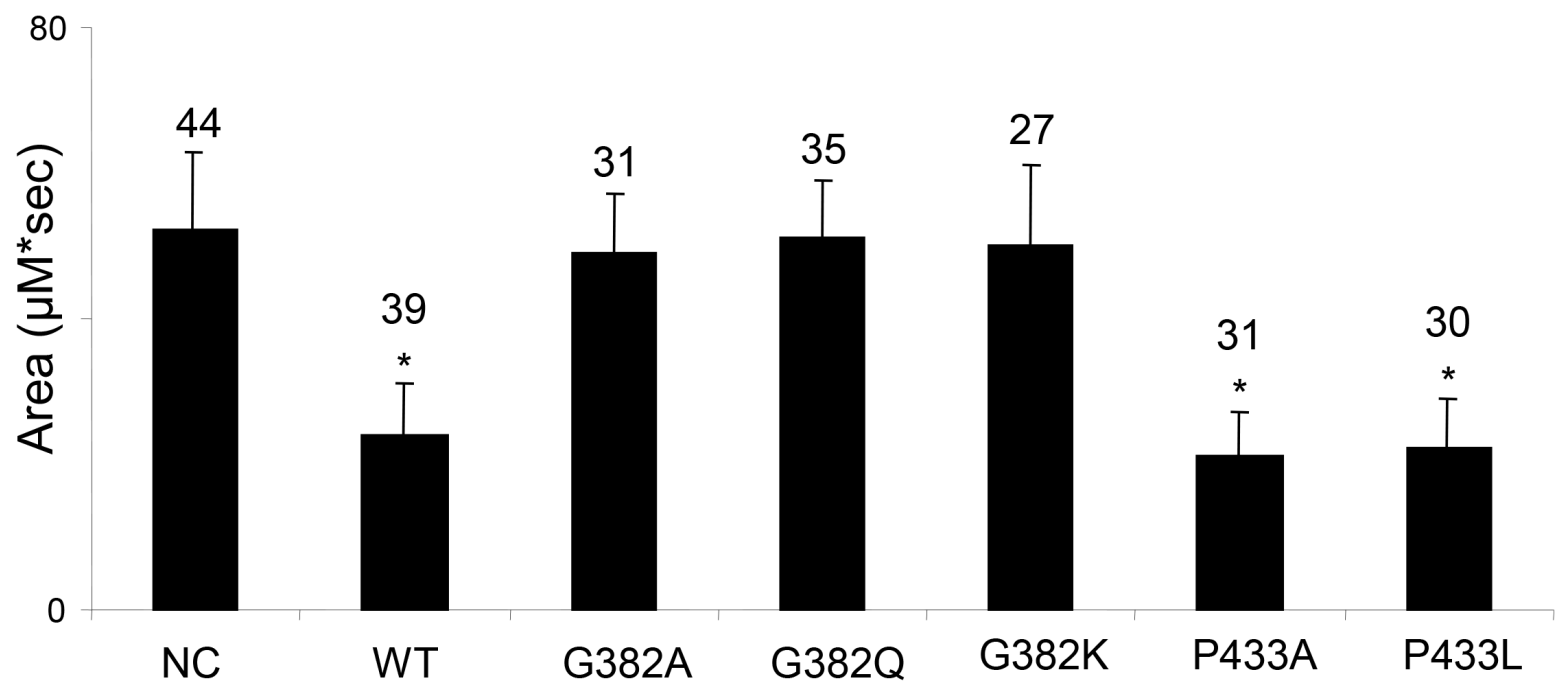

Figure 9: Study of PSEN1 mutants in low conductance ER Ca ${ }^{2+}$ leak assay. The histogram shows the mean size of ionomycin (IO)-induced $\mathrm{Ca}^{2+}$ pool $( \pm \mathrm{SD})$ in PSEN1 $1^{-/} / P S E N 2^{-/} \mathrm{MEF}$ cells stably transfected with wild type (WT) or mutant PSEN constructs. pEGFP-C3 plasmid was used as a negative control (NC). ' $*$ ' $\mathrm{p}<0.05$ by ANOVA - significant $\mathrm{Ca}^{2+}$ pool changes comparing to $\mathrm{NC}$. The number of cells analyzed is indicated (n).

A

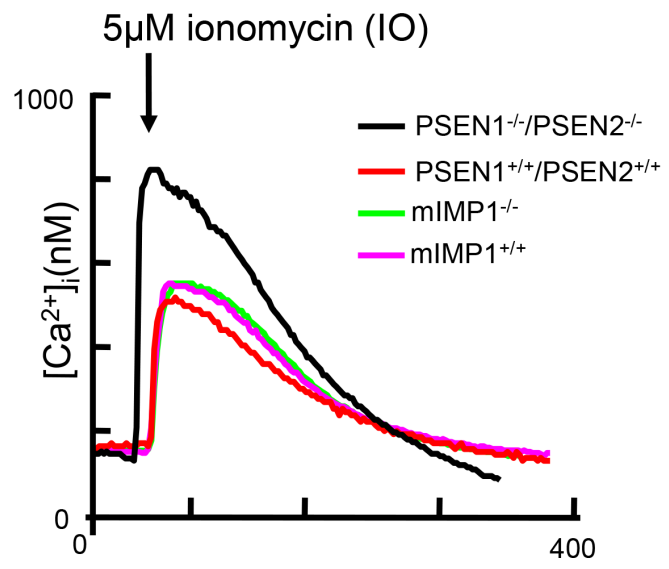

B

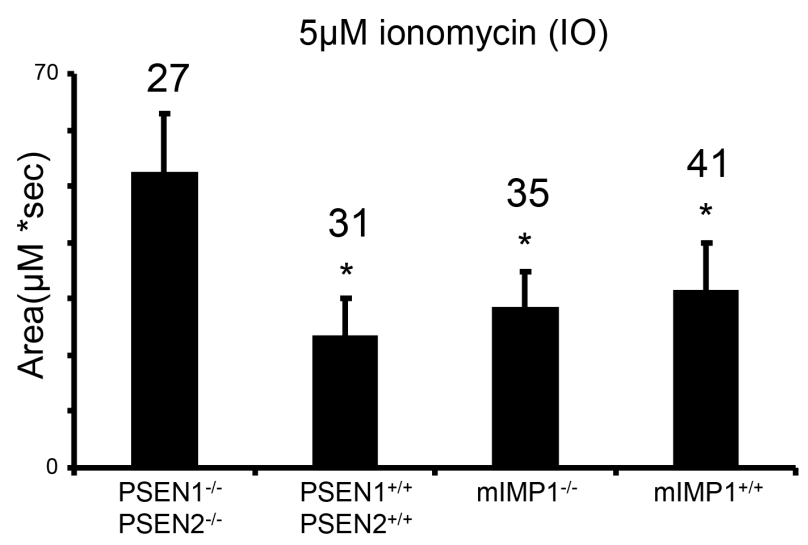

Figure 10: Low conductance ER Ca ${ }^{2+}$ leak assay demonstrates that IMP1, unlike PSEN1, is not a ion channel. (A)

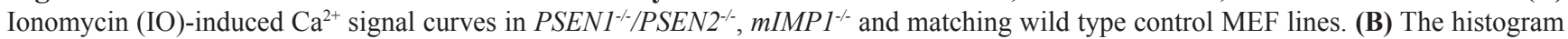
presents the mean size of IO-induced $\mathrm{Ca}^{2+}$ pool $( \pm \mathrm{SD})$ in $P S E N 1^{-/} / P S E N 2^{-/}$, mIMP1 ${ }^{-/}$and matching control MEF lines. '*' $\mathrm{p}<0.05$ by ANOVA - significant $\mathrm{Ca}^{2+}$ pool changes compared to NC. The number of cells analyzed is indicated (n). 
Ce-imp-2 are structural and functional orthologues (Figure $1 \mathrm{~B}$ and $12 \mathrm{~A})$.

In cultured cells, both human IMP1/SPP and CeIMP-2 are capable of cleaving human PSEN1 holoprotein. Ce-IMP-2 had the high proteolytic efficiency, which is consistent with a functional relationship between hIMP1 and Ce-IMP-2 orthologous proteins (Figure 7A). To determine whether Ce-IMP-2 is capable of cleaving a C-terminal PSEN1 fragment, we expressed a C-terminal derivative (corresponding to the PSEN1 form processed by "presenilinase") with hIMP1 and Ce-IMP-2 in double knockout mouse $P S E N 1^{-/} / P S E N 2^{-/}$cells. The efficient cleavage of the $\mathrm{C}$-terminus fragment was in the same domain and likely in an identical site that we described in the PSEN1 holoprotein (Figure 7B).

We reported previously that inhibition of the $\mathrm{Ce}$ imp-2 gene by microinjection of Ce-imp-2 dsRNA or feeding worms with $E$. coli, producing Ce-imp-2 dsRNA, resulted in slow growth, uncoordinated movement, reduced brood size, incomplete shedding of cuticle (ISC) as well as embryonic and larval death [48]. Here, we confirm these phenotypes in the Ce-imp-2 knockout strain tm1397, bearing a 536-bp deletion of the promoter, exon 1 and part of exon 2, and the Ce-imp- $1 \times$ Ce-imp-2 double knockout strain tm $827 \times \operatorname{tm} 1397$ (Figure 12B). We analyzed the F1 progeny of Ce-imp-2 ${ }^{+-}(\operatorname{tm} 1397)$ and Ce-imp-1-1/Ce-imp-2+- $(\operatorname{tm} 827 \times \operatorname{tm} 1397)$ worms and described the phenotypes of single or double knockouts (Ce-imp- $2^{-/}$or Ce-imp-1//Ce-imp- $\left.2^{-/}\right)$, confirmed by genotyping. The major observed phenotype was larvae death, about $30 \%$ of animals were able to generate eggs, but all the F2 progeny was inviable (Figure 12C, 12D).

We then tested the effect of mutations in the Ce-imp-2 gene in the rescue assays performed in the tm1397 Ce-imp-2 knockout strain (Figures 12, 13; Supplementary Figure 5). C. elegans G350A and P417A mutations, corresponding to human G262A and P317A, successfully rescued the embryonic lethality on a $\mathrm{Ce}$ imp- $2^{-/}$background (Figure 13), although the progeny number was overall lower compared to the Ce-imp-2 wild type construct (Figure 13). Mutations with distant physicochemical properties G350K and P417L showed no ability to rescue the mutant phenotypes compared to $\mathrm{Ce}$ imp-2 single and Ce-imp-1 $\times$ Ce-imp-2 double knockout strains (Figure 14).

\section{DISCUSSION}

Uncoupling the AD-related and physiologically important functions of presenilins represents a promising approach in the search for novel strategies for AD therapy. Genetically inherited forms of PSENs bearing the AD mutations most likely do not effect the early development of the organism, but rather, accumulate deleterious effects throughout the lifetime of the individual. Less dramatic early effects of the mutations on CNS function and development, however, cannot be excluded $[85,86]$. Evolutionary analysis of two distantly related families of PSEN and IMP/SPP intramembrane di-aspartyl proteases shows a highly conserved amino acid signature around invariant aspartates in two transmembrane domains and the PAL motif at the C-terminal domain (Supplementary Figure 1). Here, we studied whether PSEN1 amino acid substitutions in the conserved regions of the protein have differential effects on PSEN1 proteolytic and non-proteolytic functions (Supplementary Figure 2). A similar mutational remodeling analysis was performed
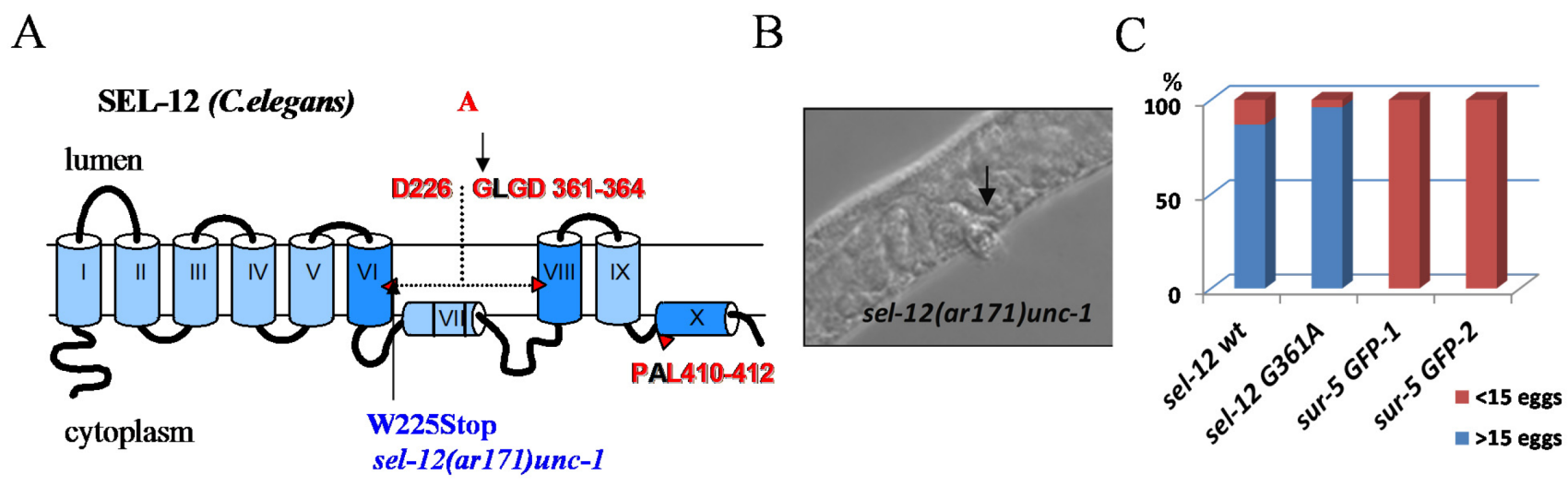

Figure 11: Rescue of sel-12 loss-of-function mutant phenotype in C. elegans. (A) Schematic representation of C. elegans SEL12 protein (human PSEN1 homolog). The Sel-12 mutant isoform was generated with the G361A mutation (analogous to human G382A) introduced into the conservative amino acid motif of SEL-12. The sel-12(ar171)unc-1 strain contains a W225Stop mutation that results in truncated protein lacking domains that are critical for SEL-12 proteolytic function. (B) Egg-laying defective (Egl) phenotype in sel12(ar171)unc-1 strain. (C) The Egl phenotype is successfully rescued by injection of sel-12 wt and sel-12 G361A constructs but not by sur-5 GFP plasmid alone. Percentage of animals laying $<15$ or $>15$ eggs is shown. Number of analyzed animals for each strain: sel-12 wt, $\mathrm{n}=61$; sel-12 G361A, $\mathrm{n}=51 ; 2$ control strains: sur-5 GFP-1, n=50; sur-5 GFP-2, $\mathrm{n}=50$. 
for the IMP1/SPP protein, which belongs to the family of evolutionarily ancient proteins distantly homologous to presenilins.

Previous in vivo and in vitro studies have shown that aspartates at positions 257 and 385 of PSEN1 play an essential role in $\gamma$-secretase proteolysis [4, 6, 83, 87-89]. These results were confirmed in our study.

The C-terminal proline 433 of PSEN1 has been described as being critical for $\gamma$-secretase function, participating in stable complex formation and catalytic pore structure [90-94, 28]. Our data demonstrate that substitutions of the conserved proline to structurally distant, but not to similar amino acids, suppress the proteolytic activity of PSEN1. However, PSEN1 with any mutation in this position can restore the normal $\mathrm{Ca}^{2+}$ leak function in PSEN1 knockout cells [28].
Mutation of the conserved leucine 435 of PSEN1 was found in familial cases of early onset AD with the unusual phenotype of cotton wool plaques [95, 96]. In our study, substitutions to structurally distant amino acids in this position have a prominent inhibitory effect on proteolytic function of PSEN1 with complete inhibition of Notch1 proteolysis and a strong inhibition of APP $\varepsilon$-proteolysis. Presenilinase function was also inhibited by L435D mutation, but to a lesser extent. Another unusual phenotype for AD, "Lewy bodies," is associated with deletion of threonine $440[97,98]$. We have shown that both PSEN1 T440D and T440V support cleavage of various substrates.

PSEN1 with a G382A mutation in the highly conserved motif of the second aspartate does not change physiologically essential proteolytic properties of the
A

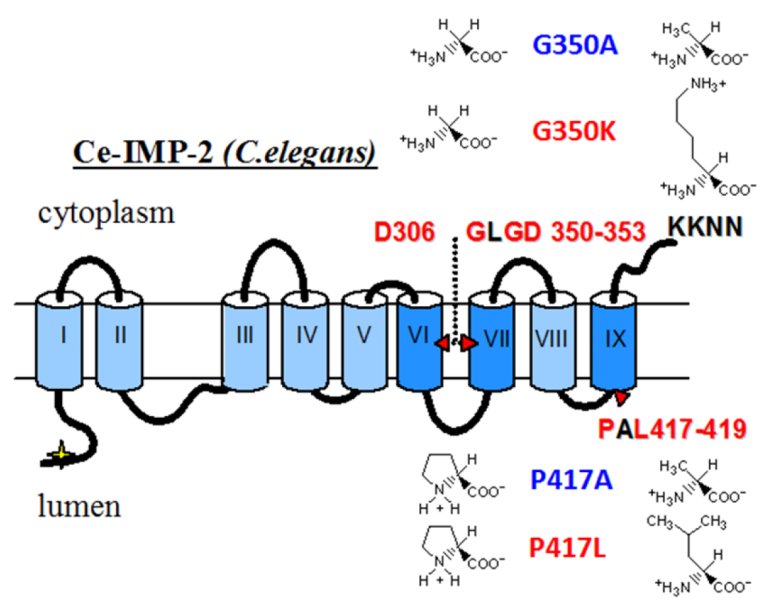

B

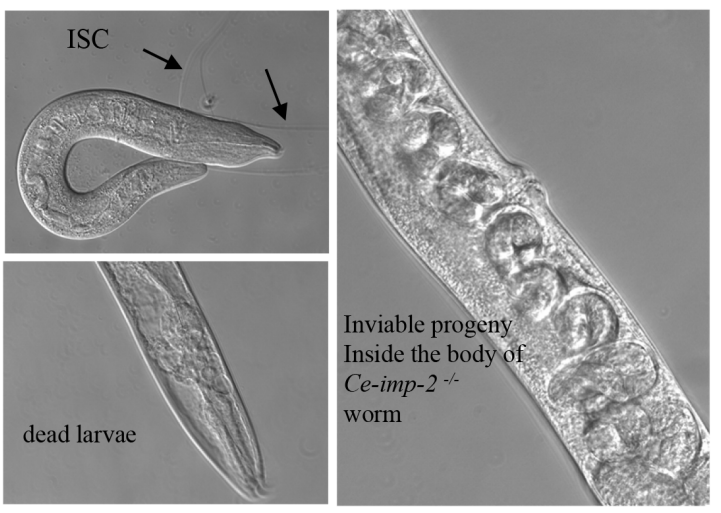

C

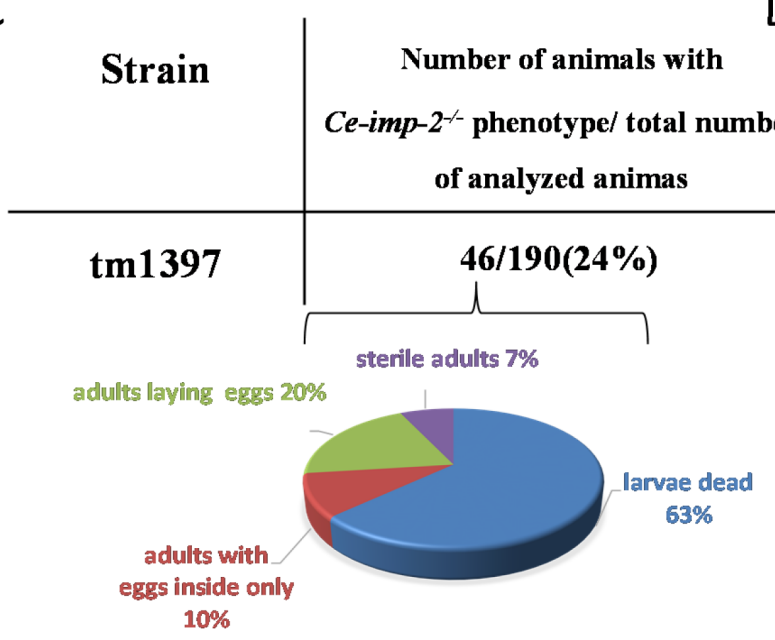

D

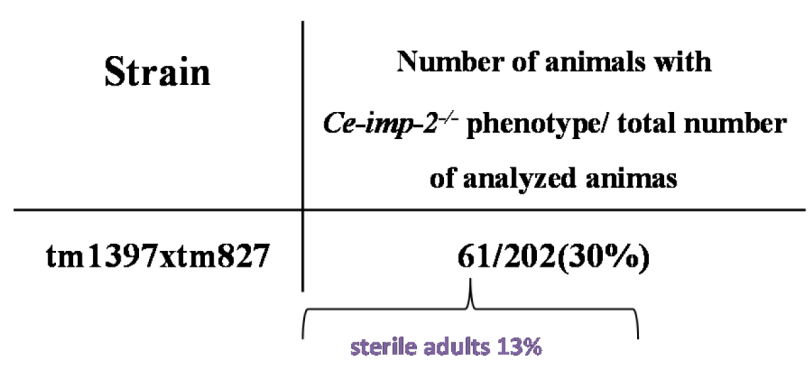

adults laving eggs $11 \%$

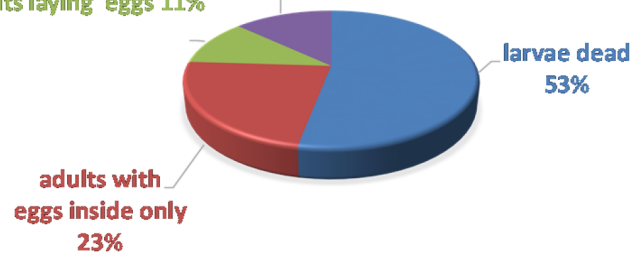

Figure 12: (A) C.elegans Ce-IMP-2 protein structure and mutations studied. Functionally important super-conservative sites (D306, GLGD 350-353, PAL 417-419) are indicated in red. (B) The loss-of-function of Ce-imp-2 (homolog of human SPP/hIMPl) leads to two major defects: embryonic death and a larvae death/molting defect (black arrows) [48]. (C, D) Detailed analysis of phenotypes in progeny

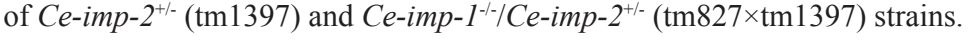


protein. The PSEN1 G382A mutation was functionally active in presenilinase, Notch and APP $\varepsilon$-proteolytic assays. Transgenic C. elegans experiments showed a successful rescue of an egg-laying defect linked to Notch proteolysis by the G361A Sel-12 construct. Distant mutations G382 K/L/Q/V completely abolished Notch1 and APP $\varepsilon$-site proteolysis and have a strong inhibitory effect on presenilinase cleavage. The G382 position is critical for supporting normal $\mathrm{Ca}^{2+}$ signaling, as none of the mutants at this position were able to restore normal $\mathrm{Ca}^{2+}$ leak function (Figure 9 and [28]). The most unexpected results were obtained in the $A \beta$ peptide assay. While PSEN1 G382L lacks both $\varepsilon$ - and $\gamma$-proteolytic activities and does not produce any A $\beta$ peptides, the PSEN1 G382A mutant retains the $\varepsilon$-cleavage activity, but significantly reduces the total production of $A \beta$ peptides. In the reported data the occurrence of $A \beta 40$ and $A \beta 42 / 43$ fragments was detected for the G382A PSEN1 mutant in HEK293 cells expressing APP with the Swedish mutation [99]. HEK293 cells have a substantial endogenous PSEN1 activity [48]. In our study, we used a PSEN1, PSEN2 double knockout MEF model for expression of the mutant PSEN isoforms, thereby excluding any effect of endogenous PSEN activity. We also used a single-amino acid high resolution PAAG assay and noticed the minor production of a novel $A \beta$ - peptide form that does not correspond to $A \beta 40$ or $A \beta 42$. We demonstrated that the PSEN1 G382A mutation retains Notch1-proteolytic activity, which has also been described in [99]. However, PSEN1 G382A was reported to block the processing of the cell membrane glycoprotein CD44 [99]. Nonetheless, our data revealed that Sel-12 G361A transgenic worms with no endogenous sel-12 presenilin activity are viable for multiple generations, providing further evidence that proteolytic activity of PSEN in processing of Notch is an essential biological function of PSEN.

Here we showed that both $C$. elegans Ce-IMP-2 and human hIMP1/SPP proteins are capable of cleaving the same multipass transmembrane protein (PSEN1holoprotein and -CTF) in co-transfection experiments using mammalian cells (Figure 7). Interestingly, CeIMP-2 induced cleavages with efficiency higher than those observed for hIMP1. Despite strong structural similarities, the Ce-IMP-2 and hIMP1 proteins have differences in some domains, particularly at the $\mathrm{N}$-terminus. We also observed that human IMP1/SPP likely forms dimeric complexes, while the Ce-imp2 protein homolog does not (data not shown). Altogether, this may explain the difference in efficiency of cleavage of the same substrate between $C$. elegans and human IMP/SPP homologs. The

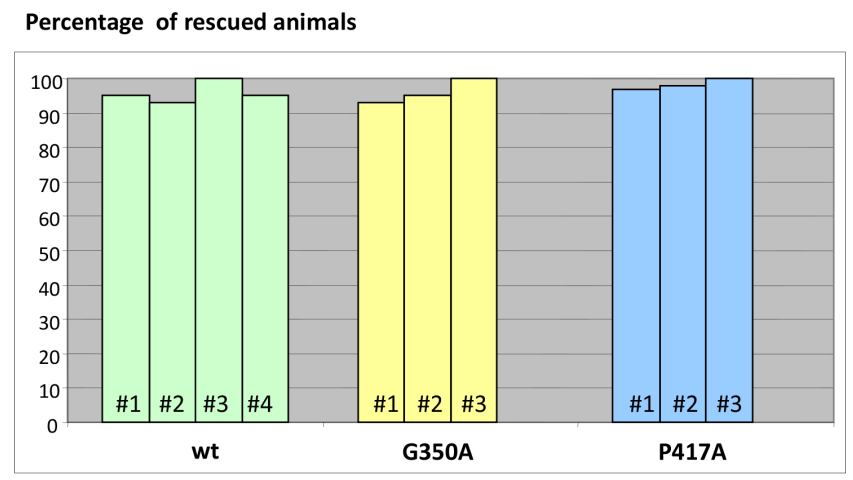

Percentage of animals with progeny number $>80$

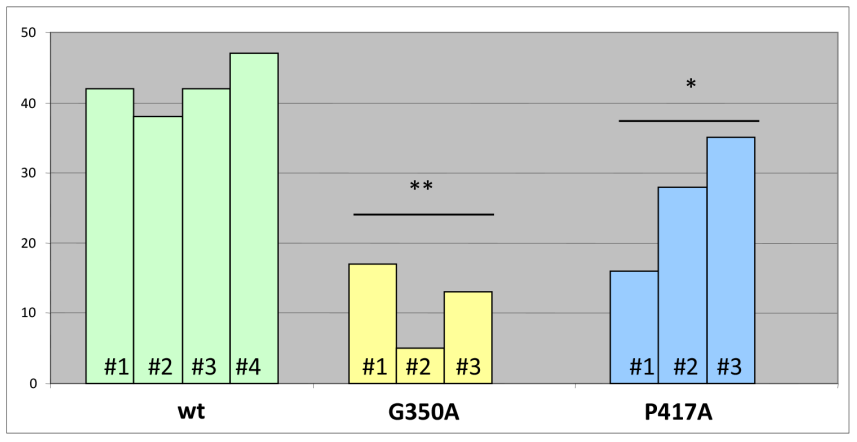

\begin{tabular}{|c|c|c|}
\hline $\begin{array}{c}\text { Transgenic } \\
\text { Strain }\end{array}$ & $\begin{array}{c}\text { Number of } \\
\text { rescued } \\
\text { animals/Total } \\
\text { number of } \\
\text { analyzed } \\
\text { animals (\%) }\end{array}$ & $\begin{array}{c}\text { Number of } \\
\text { animals with } \\
\text { progeny } \\
\text { number } \\
\text { >80/Number of } \\
\text { rescued } \\
\text { animals (\%) }\end{array}$ \\
\hline wt \#1 & $38 / 40(95 \%)$ & $16 / 38(42 \%)$ \\
\hline wt \#2 & $53 / 57(93 \%)$ & $20 / 53(38 \%)$ \\
\hline wt \#3 & $60 / 60(100 \%)$ & $25 / 60(42 \%)$ \\
\hline wt \#4 & $58 / 61(95 \%)$ & $27 / 58(47 \%)$ \\
\hline G350A \#1 & $52 / 56(93 \%)$ & $9 / 52(17 \%)$ \\
\hline G350A \#2 & $38 / 40(95 \%)$ & $2 / 38(5 \%)$ \\
\hline G350A \#3 & $60 / 60(100 \%)$ & $8 / 60(13 \%)$ \\
\hline P417A \#1 & $58 / 60(97 \%)$ & $9 / 58(16 \%)$ \\
\hline P417A \#2 & $60 / 61(98 \%)$ & $17 / 60(28 \%)$ \\
\hline P417A \#3 & $60 / 60(100 \%)$ & $21 / 60(35 \%)$ \\
\hline
\end{tabular}

Figure 13: Rescue of $\boldsymbol{C}$-imp-2 knockout phenotype in $\boldsymbol{C}$. elegans. The constructs producing Ce-IMP-2 wild type and several mutant isoforms were generated. Several independent viable transgenic strains on Ce-imp- $2^{-/-}$(tm1397) background were obtained by picking 20-30 roller phenotype animals (pRF4 was used as a co-marker) from injected Ce-imp- $2^{+/}$worm progeny. Rescue of Ce-imp-2 knockout phenotypes was analyzed in 40-61 animals for each transgenic Ce-imp- $2^{-/-}$strain. Worms that can reach adult stage and have viable progeny were considered as rescued. The loss-of function Ce-imp-2 phenotype was rescued by G350A, P417A Ce-imp-2 constructs. 
data also indicate that $C e$-imp-2 is a true orthologue of human IMP1/SPP.

We also searched available SNP databases to identify if any mutation in PSEN1 and hIMP1/SPP that we studied can be found in common human populations. We have not identified such SNPs in more than 2,500 human genomes in the 1000 Genomes Project catalog [100]. The Ensemble variants database contains reports for PSEN1 AD-mutations M146V, C410Y and also AD-linked mutations in protein positions 284 and 435 , which differ from the mutations in this position described in our paper. Interestingly, the PSEN1 D257N somatic mutation, leading to PSEN1 haploinsufficiency, has been found in lung carcinoma" (Supplementary Table 1). Amino acid substitutions in positions 245 and 319 of hIMP1 were found in malignant melanoma and endometrium carcinoma correspondingly (Supplementary Table 2). Thus, it would be of interest to elucidate further the potential role of these proteases in cancer.

In summary, we confirmed that any mutations at functionally essential aspartates of members of two distantly related families of intramembrane proteases, PSEN1 and IMP1, completely abolish all their proteolytic activities. Mutations in other highly conserved sites reduce, but do not completely suppress, at least some of the proteolytic activities of PSEN1. Substitutions to structurally distant amino-acids in the most conserved sites most dramatically change efficacy of proteolytic cleavages. Amino acid substitutions in less conserved sites (e.g. P284 and T440 in PSEN1) can reduce substrates proteolysis, but to a much lesser extent. For PSEN1, among different proteolytic assays, "presenilinase" activity is the most resistant to all mutation modifications in highly conserved sites. The PSEN1 G382A mutant retains the functionally important Notch1 and APP $\varepsilon$-cleavage activities but has reduced APP $\gamma$-cleavage activity and does not support the $\mathrm{Ca}^{2+}$ leak function, but rescues the lethality of $C$. elegans Ce-imp-2 knockout. We also provided evidence that IMP1/ SPP is not a $\mathrm{Ca}^{2+}$ channel as described for the structurally related PSEN1.

The important finding is that a single amino acid alteration in transmembrane domain 7 of PSEN1 can reduce the AD-related intramembrane $\gamma$-secretase activity but retain the biologically important juxtamembrane proteolytic function of PSEN1. These data raise the idea that uncoupling AD- and biologically-essential functions of presenilins may represent a promising novel therapeutic approach.

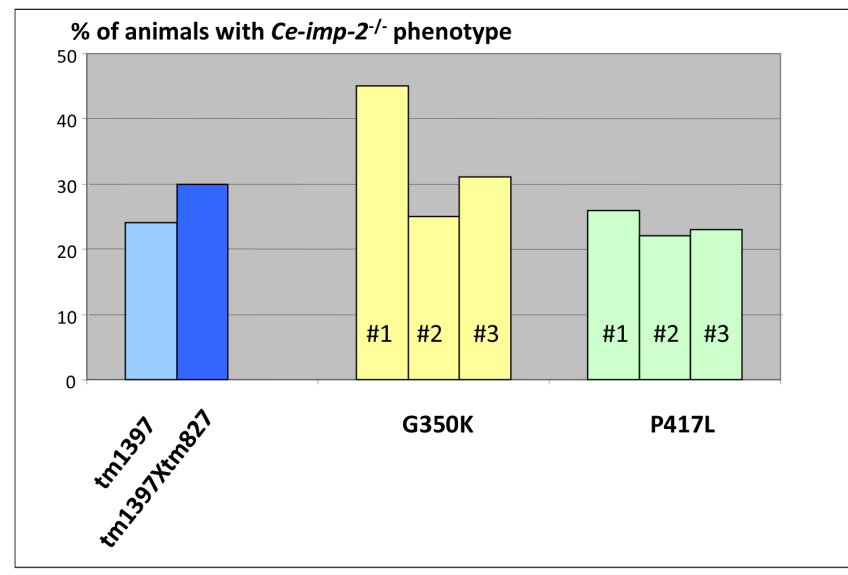

\begin{tabular}{|c|c|c|}
\hline $\begin{array}{c}\text { Transgenic } \\
\text { Strain, } \\
\text { progeny of } \\
\text { Ce-imp2 }\end{array}$ & $\begin{array}{c}\text { Number of } \\
\text { animals } \\
\text { displayed } C e- \\
\text { imp-2- } \\
\text { phenotype/Total } \\
\text { number of } \\
\text { analyzed } \\
\text { progeny (\%) }\end{array}$ & $\begin{array}{c}\text { Number of non } \\
\text { roller wt } \\
\text { phenotype } \\
\text { animals/ Total } \\
\text { number of wt } \\
\text { phenotype } \\
\text { animals (\%) }\end{array}$ \\
\hline G350K \#1 & $105 / 236(45 \%)$ & $17 / 131(13 \%)$ \\
\hline G350K\#1 & $0 / 100(0 \%)$ & $30 / 100(30 \%)$ \\
(*progeny of & & \\
\hline G350K \#2 & $58 / 229(25 \%)$ & $22 / 171(13 \%)$ \\
\hline G350K \#3 & $65 / 210(31 \%)$ & $15 / 145(10 \%)$ \\
\hline P417L \#1 & $67 / 255(26 \%)$ & $13 / 188(7 \%)$ \\
\hline P417L \#2 & $46 / 211(22 \%)$ & $50 / 165(30 \%)$ \\
\hline P417L \#3 & $48 / 212(23 \%)$ & $29 / 164(18 \%)$ \\
\hline
\end{tabular}

Figure 14: No rescue of $C$-imp-2 knockout phenotypes was found by constructs producing Ce-IMP-2 G350K, P417L mutant proteins. If none of the 20-30 roller phenotype (transgenic marker) worms, progeny of injected Ce-imp-2 $2^{+/}$worms, displayed rescue phenotype on $C e$-imp- $2^{-/}$background, then $\sim 200$ single worms, synchronized mixed viable progeny of several transgenic $C e-i m p-2^{+/-}$ animals, were analyzed. In addition, for G350K strain \#1, we checked phenotypes of Ce-imp- $2^{+/+}$animals progeny. The rate of the losing transgenic status was estimated as percentage of non-roller wild type phenotype animals/total number of wild type phenotype animals. P-value significance codes: ' $* *$ ' $<0.01,{ }^{\prime}{ }^{*}{ }^{\prime}<0.05$. 


\section{MATERIALS AND METHODS}

\section{Plasmid constructs for expression in mammalian cell cultures}

Human IMP1 (hIMP1) and PSEN1 (hPSEN1) wild type constructs were described previously [47]. A

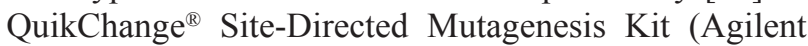
Technologies Inc., Santa Clara, CA, USA) was used to incorporate mutations in the hIMP1 and hPSEN1 genes (Supplementary Tables 1 and 2). PSEN1 D385A and APP Swedish mutant (APP695 $\Delta$ NL) constructs were obtained from the Mayo Clinic (Mayo Clinic, Jacksonville, FL). mNotch1 (myc-tagged Notch $\Delta \mathrm{E}$ and NICD) constructs were kindly provided by Dr. R. Kopan (Washington University School of Medicine, St. Louis, MO, USA). pcDNA Flag-HCVcore-HA plasmid was a gift from Dr. Kohji Moriishi (Osaka University, Osaka, Japan). QuikChange ${ }^{\circledR}$. pcDNA4/myc-His B or pcDNA3 plasmids from Invitrogen (Thermo Fisher Scientific, Waltham, MA, USA) were used as mock controls. cDNA clones for $\mathrm{Ce}$ imp-1, Ce-imp-2, and Ce-imp-3 genes were obtained from Y. Kohara (Genome Biology Lab, National Institute of Genetics, Mishima, Japan) and cloned into pcDNA4/mycHis B plasmid (Invitrogen, Thermo Fisher Scientific) for the experiments performed in mammalian cell cultures.

\section{Mammalian cell cultures}

Knockout PSEN1/-/PSEN2 ${ }^{-/-}$and control $\mathrm{PSEN1}^{+/+} /$ $P S E N 2^{+/+}$mouse embryonic fibroblasts (MEF) were a gift from Dr. De Strooper (Center for Human Genetics, Katholieke Universiteit Leuven, and Flanders Interuniversity Institute for Biotechnology, Leuven, Belgium).

HEK293 and MEF cells were cultured in DMEM (Gibco, Thermo Fisher Scientific) containing 10\% FBS (Hyclone Laboratories, Logan, UT), 2 mM L-glutamine at $37^{\circ} \mathrm{C}$ and $1 \%$ penicillin/streptomycin, $5 \% \mathrm{CO}_{2}$. Primary cultures of MEF were generated from $13.5 \mathrm{dpc}$ hIMP1 knockout embryos and immortalized by continuous passaging (unpublished).

\section{Transfection of mammalian cell lines and immunoblotting}

Transient transfections were performed using Lipofectamine Plus Reagent (Invitrogen, Thermo Fisher Scientific) according to the manufacturer's instructions. After 24-48 hours of transfection, cells were briefly washed 2 times in cold PBS, lysed in modified RIPA-buffer (50 mM Tris-HCl, $\mathrm{pH} 7.4,1 \%$ NP-40, $0.25 \%$ deoxcholate $\mathrm{Na}, 150 \mathrm{mM} \mathrm{NaCl}, 1 \mathrm{mM}$ EDTA) supplemented with Complete Mini Protease Inhibitor Cocktail (Roche Diagnostics, Indianapolis, IN) for $15 \mathrm{~min}$ at $4^{\circ} \mathrm{C}$ and subsequently centrifuged at $14,000 \mathrm{rpm}$ for
10 min at $4^{\circ} \mathrm{C}$. A NOVEX mini-cell gel electrophoresis system (Invitrogen, Thermo Fisher Scientific) was used for protein separation and electrotransfer procedures. Cell lysates (10-20 $\mu \mathrm{g}$ of total protein) or $10 \mu \mathrm{l}$ of conditioned culture medium were mixed with $5 x$ Laemmli sample buffer with reducing agent (1x sample buffer composition: $60 \mathrm{mM}$ Tris-Cl pH 6.8, 2\% SDS, $10 \%$ glycerol, $5 \%$ $\beta$-mercaptoethanol, $0.01 \%$ bromophenol blue) centrifuged at $12,000 \mathrm{rpm}$ for $5 \mathrm{~min}$ with or without prior boiling for $5 \mathrm{~min}$, and loaded onto SDS PAAG mini-gels (Invitrogen, Thermo Fisher Scientific). Prestained molecular weight markers (Invitrogen, Thermo Fisher Scientific) were loaded into a separate well. Electrophoresis was run either in $10 \%$ (PSEN1, HCV detection) or $8 \%$ (Notch detection) Tris-Glycine PAAG or in Novex ${ }^{\circledR} 10-20 \%$ Tricine Gel (for APP-CT detection) in 1X SDS running buffer at 125 V. After electrotransfer, Immobilon-P PVDF membranes (EMD Millipore, Billerica, MA USA) were washed in TBS-T buffer (50 mM Tris-HCl, pH 7.4, $150 \mathrm{mM} \mathrm{NaCl}$, $0.05 \%$ Tween 20) 1 time for $10 \mathrm{~min}$ and 3 times for 5 min, incubated in blocking buffer (5\% milk in TBS-T) at room temperature for 1 hour and placed in $10 \mathrm{ml}$ of hybridization buffer ( $1 \%$ milk in TBS-T), containing primary antibodies in 1:500-1:5000 dilution, at $4^{\circ} \mathrm{C}$ overnight. After incubation with appropriate secondary antibodies, signal visualization was performed using an ECL Western blotting detection reagent kit and exposure to an X-ray film or via image capturing using a VersaDoc 5000 imaging system (Bio-Rad Laboratories, Hercules, CA). Experiments were replicated multiple times ( $\geq 3$ ).

Polyclonal rabbit antibodies against hPSEN1 N-terminal polypeptide and CTF were described previously [47]. Antibody against c-myc epitope for IMP1 and Notch detection was obtained from Invitrogen (Thermo Fisher Scientific). The released APP intracellular fragments were detected in supernatants using polyclonal APP CTF antibody (Sigma-Aldrich). For detection of A $\beta$ peptides, mAb 1E8 (Bayer-Schering Pharma AG, Berlin, Germany or provided by T. Dyrks, Schering, Berline, Germany) was used while mAb 22C11 was used for detection of N-terminal APP fragments (Chemicon, EMD Millipore). For HCV detection, monoclonal mouse antiFLAG (Sigma-Aldrich) was used.

\section{Cell-free intramembrane cleavage assay}

For intramembrane cleavage assays, $P S E N 1^{-1} / P S E N 2^{-1-}$ MEF cells were transfected with either APP $695 \triangle \mathrm{NL}$ or Notch $\triangle E$ and one of the PSEN1 isoforms or mock plasmid. After 48 hours of transfection, cells were washed twice with ice-cold PBS, scraped off the dishes, resuspended in $0.5 \mathrm{ml}$ of hypotonic homogenization buffer (10 mM HEPES, $\mathrm{pH}$ 7.2; protease inhibitors cocktail), incubated on ice for 1 hour and frozen in liquid nitrogen. Frozen cells were thawed on ice for 1 hour and homogenized by passing through a 22-gauge hypodermic needle 5 times. Homogenates were 
centrifuged at 1000 at $4^{\circ} \mathrm{C}$ for $10 \mathrm{~min}$ and post-nuclear supernatants were saved. To isolate crude membranes, postnuclear supernatants were subjected to centrifugation at $20000 \mathrm{~g}, 4^{\circ} \mathrm{C}$ for $45 \mathrm{~min}$ and the pellets were resuspended in assay buffer (150 mM Sodium Citrate, pH 6.4, 5 mM EDTA, protease inhibitors cocktail). Intramembrane cleavage was induced by incubation of the samples at $37^{\circ} \mathrm{C}$ for 2 hours. Reactions were stopped by placing samples on ice, and membranes precipitated by centrifugation at $16000 \mathrm{~g}, 4^{\circ} \mathrm{C}$ for $30 \mathrm{~min}$. The released cleavage fragments were detected in supernatants and analyzed by immunoblot.

\section{Immunoprecipitation of $A \beta$ secreted in cell culture media}

After 24 hours of transfection, plates were washed twice with $1 \times$ DPBS and incubated for 24 hours in serum-free O-MEM. Conditioned media were collected, centrifuged at $3000 \mathrm{~g}$ for $10 \mathrm{~min}$ and supernatants were subjected to immunoprecipitation as described in [101]. Briefly, $400 \mu \mathrm{l}$ of medium were mixed with $100 \mu \mathrm{l}$ of 5x RIPA buffer (2.5\% IGEPAL CA-630, 1.25\% sodium deoxycholate, $0.25 \%$ SDS, $750 \mathrm{mM} \mathrm{NaCl}, 250 \mathrm{mM}$ HEPES, pH 7.4) supplemented with 1 tablet of Complete Mini Protease Inhibitor Cocktail per $2 \mathrm{ml}$ of 5x RIPA. Magnetic beads $(25 \mu \mathrm{l}$; DynaBeads, Thermo Fisher Scientific) coupled with monoclonal antibody $1 \mathrm{E} 8$ (1 $\mu \mathrm{g}$ of mAb 1 E8 per $1.68 \times 10^{7}$ beads) per reaction were added. Samples were incubated on a shaker at $4{ }^{\circ} \mathrm{C}$ overnight. After washing in PBS, $0.1 \%$ BSA three times and one time in $10 \mathrm{mM}$ Tris- $\mathrm{HCl}, \mathrm{pH} 7.4, \mathrm{~A} \beta$ peptides were eluted from the magnetic beads in sample buffer containing $0.36 \mathrm{M}$ bis-Tris, 0.16 M N, N'-bis-(2-hydroxyethyl)-glycine, 1\% SDS, $15 \%$ sucrose, and $0.004 \%$ bromophenol blue, $2.5 \%$ DTT at $95^{\circ} \mathrm{C}$ for $5 \mathrm{~min}$.

\section{SDS-PAGE of A $\beta$ peptides}

$\mathrm{A} \beta$ peptides were separated in $0.5 \mathrm{~mm}$ thick $13 \% \quad \mathrm{~T} \% / 5 \% \quad \mathrm{C} / 8 \mathrm{M}$ urea bicine/bis-Tris/Tris SDSPAGE minigels, (T\%-total percentage concentration of acrylamide monomer, $\mathrm{C} \%$ - the percentage of crosslinker relative to the total acrylamide monomer) [101]. Electrophoresis was for 2 hours at a constant current of $12 \mathrm{~mA}$ per gel at ambient temperature. $\mathrm{A} \beta$ peptides were transferred onto Immobilon-P PVDF membranes (Millipore, Billerica, MA USA) using a TE70 ECL Semi-Dry Transfer Unit (GE Healthcare Life Sciences, Piscataway Township, NJ, USA) for $30 \mathrm{~min}$ at $1 \mathrm{~mA} / \mathrm{cm}^{2}$ at room temperature as described in [102]. After transfer was completed, membranes were briefly washed in deionized water, boiled in $1 \times$ PBS for $3 \mathrm{~min}$ in a microwave, blocked in Roti-Block blocking buffer (Carl Roth GmbH, Karlsruhe, Germany) and incubated with primary mAb $1 \mathrm{E} 8$ diluted $1: 300$ overnight at $4{ }^{\circ} \mathrm{C}$. After a series of washes in PBS-T buffer $(1 \times \mathrm{PBS}, 0.075 \%$
Tween 20), membranes were incubated with secondary anti-mouse horse radish peroxidase-conjugated antibody (Pierce Biotechnology, Thermo Fisher Scientific) 1:5000 for $1 \mathrm{~h}$ at room temperature, washed $3 \times 10 \mathrm{~min}$ in PBS-T and subsequently developed for $5 \mathrm{~min}$ with ECL Advance reagents (GE Healthcare Life Sciences). Signals were detected using a VersaDock 5000 MP Imaging System, and analyzed using Quantity One 4.6.3 software (BioRad Laboratories, Hercules, CA, USA). Along with bicine/bis-Tris/Tris SDS-PAGE, $10 \mu \mathrm{l}$ of each sample of conditioned medium were analyzed by Tris-glycine PAAG electrophoresis-immunoblot with monoclonal 22C11 antibody, that recognizes full length APP. To normalize signals of $A \beta$ peptides, serial dilutions of synthetic $A \beta$ peptides (A $\beta$ 1-37, $A \beta$ 1-38, $A \beta$ 1-39, $A \beta$ 1-40, $A \beta$ 1-42, A $\beta$ 2-42, Bachem, Bubendorf, Switzerland) were used [103].

\section{C. elegans experiments}

Standard methods of $C$. elegans handling and culture were applied [104]. N2 Bristol strain was used as the wild type. Sel-12(ar171)unc-1 (e538) was provided by I. Greenwald (Columbia University, New York, USA). Tm827 (Ce-imp-1 knockout), tm1397 (Ce-imp-2 knockout) and tm1654 (Ce-imp-3 knockout) were provided by the Mitani Laboratory, Tokyo Women's Medical University School of Medicine, Japan and outcrossed 3-5 times to the N2 strain. A C. elegans $\sim 6 \mathrm{~kb}$ sel-12 genomic fragment containing $\sim 3 \mathrm{~kb}$ of the $5^{\prime}-$ and $\sim 0.8 \mathrm{~kb}$ of the $3^{\prime}$ - regulatory regions were cloned into the L4440 vector. Ce-imp-2 constructs are described in Supplementary Figure 5. Mutations in the sel-12 and Ce-imp-2 genes were introduced using a QuikChange $^{\circledR}$ Site-Directed Mutagenesis Kit (Stratagene, Agilent Technologies). RNA interference (RNAi) by dsRNA feeding and germ-line injections were performed as previously described [48]. Sur-5 GFP or $p R F 4$ plasmids were used as germ-line co-injection markers. Ce-imp knockout and transgenic strains were genotyped accordingly (Supplementary Figure 5, Supplementary Table $3)$. The progeny of the heterozygous deletion mutant $\mathrm{Ce}$ imp-2 were analyzed by single worm PCR.

\section{ER Ca2 ${ }^{+}$channel leak study}

Experimental methodology for measuring ER $\mathrm{Ca}^{2+}$ channel leak was previously described [27, 28].

\section{Statistical analysis}

Plotted values represent mean \pm standard error of the mean. Comparisons of more than two groups were carried out using one-way ANOVA and unpaired T-test against WT values as the control group (Figure 2-4, 6, 8 ). For the analysis of total A $\beta$ in PSEN1 mutants (Figure 5) and C. elegans experiments (Figure 13-14) WT values were converted to Z-score using mutant data and two- 
tailed P-value was calculated. In all cases $\mathrm{P}<0.05$ was considered to be statistically significant after adjusting for multiple testing with Benjamini \& Hochberg procedure.

\section{ACKNOWLEDGMENTS}

We thank Dr. R. Kopan for mNotch1 plasmids, Dr. De Strooper for knockout MEF cells, and the Mayo Clinic for presenilin and APP mutant constructs, Dr. K. Moriishi (Research Institute for Microbial Diseases, Osaka University, Japan) for the plasmid containing the gene encoding the HCV core protein; Dr. J. Wiltfang for mAb 1E8 antibodies, Dr. Mitani, Tokyo Women's Medical University School of Medicine and Dr. Y. Kohara, Genome Biology Lab, National Institute of Genetics, Mishima for C. elegans strains and cDNA clones and members of Dr. Craig C. Mello's laboratory (UMASS Medical School, USA) for consultations and technical support. We thank our laboratory personal for technical support of the work.

This work was funded by NIH/NIA AG029360, and in part by NIH/NINDS NS045854, American Alzheimer's Association, Russian Science Foundation \#14-44-00077 (in part, C.elegans work) and \#14-50-00029 (bioinformatics).

\section{CONFLICTS OF INTEREST}

The authors have no conflicts of interest to disclose.

\section{REFERENCES}

1. Sherrington R, Rogaev EI, Liang Y, Rogaeva EA, Levesque G, Ikeda M, Chi H, Lin C, Li G, Holman K, Tsuda T, Mar L, Foncin JF, et al. Cloning of a gene bearing missense mutations in early-onset familial Alzheimer's disease. Nature. 1995; 375:754-60.

2. Rogaev EI, Sherrington R, Rogaeva EA, Levesque G, Ikeda M, Liang Y, Chi H, Lin C, Holman K, Tsuda T, Mar L, Sorbi S, Nacmias B, et al. Familial Alzheimer's disease in kindreds with missense mutations in a gene on chromosome 1 related to the Alzheimer's disease type 3 gene. Nature. 1995; 376:775-78.

3. Steiner $\mathrm{H}$, Haass $\mathrm{C}$. Intramembrane proteolysis by presenilins. Nat Rev Mol Cell Biol. 2000; 1:217-24.

4. Wolfe MS, Xia W, Ostaszewski BL, Diehl TS, Kimberly WT, Selkoe DJ. Two transmembrane aspartates in presenilin-1 required for presenilin endoproteolysis and gamma-secretase activity. Nature. 1999; 398:513-17.

5. Steiner H, Duff K, Capell A, Romig H, Grim MG, Lincoln S, Hardy J, Yu X, Picciano M, Fechteler K, Citron M, Kopan R, Pesold B, et al. A loss of function mutation of presenilin-2 interferes with amyloid betapeptide production and notch signaling. J Biol Chem. 1999; 274:28669-73.
6. Kimberly WT, Xia W, Rahmati T, Wolfe MS, Selkoe DJ. The transmembrane aspartates in presenilin 1 and 2 are obligatory for gamma-secretase activity and amyloid betaprotein generation. J Biol Chem. 2000; 275:3173-78.

7. Wang J, Brunkan AL, Hecimovic S, Walker E, Goate A. Conserved "PAL" sequence in presenilins is essential for gamma-secretase activity, but not required for formation or stabilization of gamma-secretase complexes. Neurobiol Dis. 2004; 15:654-66.

8. Laudon H, Hansson EM, Melén K, Bergman A, Farmery MR, Winblad B, Lendahl U, von Heijne G, Näslund J. A nine-transmembrane domain topology for presenilin 1 . J Biol Chem. 2005; 280:35352-60.

9. Oh YS, Turner RJ. Topology of the C-terminal fragment of human presenilin 1. Biochemistry. 2005; 44:11821-28.

10. Spasic D, Tolia A, Dillen K, Baert V, De Strooper B, Vrijens $\mathrm{S}$, Annaert W. Presenilin-1 maintains a nine-transmembrane topology throughout the secretory pathway. J Biol Chem. 2006; 281:26569-77.

11. Bai XC, Yan C, Yang G, Lu P, Ma D, Sun L, Zhou R, Scheres SH, Shi Y. An atomic structure of human $\gamma$-secretase. Nature. 2015; 525:212-17.

12. Edbauer D, Winkler E, Regula JT, Pesold B, Steiner H, Haass C. Reconstitution of gamma-secretase activity. Nat Cell Biol. 2003; 5:486-88.

13. Haass C, Steiner H. Alzheimer disease gamma-secretase: a complex story of GxGD-type presenilin proteases. Trends Cell Biol. 2002; 12:556-62.

14. De Strooper B. Aph-1, Pen-2, and Nicastrin with Presenilin generate an active gamma-Secretase complex. Neuron. 2003; 38:9-12.

15. Wang B, Yang W, Wen W, Sun J, Su B, Liu B, Ma D, Lv D, Wen Y, Qu T, Chen M, Sun M, Shen Y, Zhang X. Gammasecretase gene mutations in familial acne inversa. Science. 2010; 330:1065.

16. Pink AE, Simpson MA, Desai N, Trembath RC, Barker JN. $\gamma$-Secretase mutations in hidradenitis suppurativa: new insights into disease pathogenesis. J Invest Dermatol. 2013; 133:601-07.

17. Lilly Halts Development of Semagacestat for Alzheimer's Disease Based on Preliminary Results of Phase III Clinical Trials.

18. Xia X, Qian S, Soriano S, Wu Y, Fletcher AM, Wang $\mathrm{XJ}$, Koo EH, Wu X, Zheng H. Loss of presenilin 1 is associated with enhanced beta-catenin signaling and skin tumorigenesis. Proc Natl Acad Sci USA. 2001; 98:10863-68.

19. Qyang Y, Chambers SM, Wang P, Xia X, Chen X, Goodell MA, Zheng H. Myeloproliferative disease in mice with reduced presenilin gene dosage: effect of gamma-secretase blockage. Biochemistry. 2004; 43:5352-59. 
20. Behrens MI, Lendon C, Roe CM. A common biological mechanism in cancer and Alzheimer's disease? Curr Alzheimer Res. 2009; 6:196-204.

21. Lee TH, Pastorino L, Lu KP. Peptidyl-prolyl cis-trans isomerase Pin1 in ageing, cancer and Alzheimer disease. Expert Rev Mol Med. 2011; 13:e21.

22. Shafi O. Inverse relationship between Alzheimer's disease and cancer, and other factors contributing to Alzheimer's disease: a systematic review. BMC Neurol. 2016; 16:236.

23. Soriano S, Kang DE, Fu M, Pestell R, Chevallier N, Zheng H, Koo EH. Presenilin 1 negatively regulates betacatenin/T cell factor/lymphoid enhancer factor-1 signaling independently of beta-amyloid precursor protein and notch processing. J Cell Biol. 2001; 152:785-94.

24. Kang DE, Soriano S, Xia X, Eberhart CG, De Strooper B, Zheng H, Koo EH. Presenilin couples the paired phosphorylation of beta-catenin independent of axin: implications for beta-catenin activation in tumorigenesis. Cell. 2002; 110:751-62.

25. Meredith JE Jr, Wang Q, Mitchell TJ, Olson RE, Zaczek $\mathrm{R}$, Stern AM, Seiffert D. Gamma-secretase activity is not involved in presenilin-mediated regulation of beta-catenin. Biochem Biophys Res Commun. 2002; 299:744-50.

26. Serban G, Kouchi Z, Baki L, Georgakopoulos A, Litterst CM, Shioi J, Robakis NK. Cadherins mediate both the association between PS1 and beta-catenin and the effects of PS1 on beta-catenin stability. J Biol Chem. 2005; 280:36007-12.

27. Tu H, Nelson O, Bezprozvanny A, Wang Z, Lee SF, Hao YH, Serneels L, De Strooper B, Yu G, Bezprozvanny I. Presenilins form ER Ca2+ leak channels, a function disrupted by familial Alzheimer's disease-linked mutations. Cell. 2006; 126:981-93.

28. Nelson O, Supnet C, Tolia A, Horré K, De Strooper B, Bezprozvanny I. Mutagenesis mapping of the presenilin 1 calcium leak conductance pore. J Biol Chem. 2011; 286:22339-47.

29. Maesako M, Uemura K, Kuzuya A, Sasaki K, Asada M, Watanabe K, Ando K, Kubota M, Kihara T, Kinoshita A. Presenilin regulates insulin signaling via a gammasecretase-independent mechanism. J Biol Chem. 2011; 286:25309-16.

30. Sarasija S, Norman KR. A $\gamma$-Secretase Independent Role for Presenilin in Calcium Homeostasis Impacts Mitochondrial Function and Morphology in Caenorhabditis elegans. Genetics. 2015; 201:1453-66.

31. Esselens C, Oorschot V, Baert V, Raemaekers T, Spittaels K, Serneels L, Zheng H, Saftig P, De Strooper B, Klumperman J, Annaert W. Presenilin 1 mediates the turnover of telencephalin in hippocampal neurons via an autophagic degradative pathway. J Cell Biol. 2004; 166:1041-54.
32. Wilson CA, Murphy DD, Giasson BI, Zhang B, Trojanowski JQ, Lee VM. Degradative organelles containing mislocalized alpha-and beta-synuclein proliferate in presenilin-1 null neurons. J Cell Biol. 2004; 165:335-46.

33. Lee JH, Yu WH, Kumar A, Lee S, Mohan PS, Peterhoff CM, Wolfe DM, Martinez-Vicente M, Massey AC, Sovak G, Uchiyama Y, Westaway D, Cuervo AM, Nixon RA. Lysosomal proteolysis and autophagy require presenilin 1 and are disrupted by Alzheimer-related PS1 mutations. Cell. 2010; 141:1146-58.

34. Coen K, Flannagan RS, Baron S, Carraro-Lacroix LR, Wang D, Vermeire W, Michiels C, Munck S, Baert V, Sugita S, Wuytack F, Hiesinger PR, Grinstein S, Annaert W. Lysosomal calcium homeostasis defects, not proton pump defects, cause endo-lysosomal dysfunction in PSENdeficient cells. J Cell Biol. 2012; 198:23-35.

35. Nicolas M, Wolfer A, Raj K, Kummer JA, Mill P, van Noort M, Hui CC, Clevers H, Dotto GP, Radtke F. Notch1 functions as a tumor suppressor in mouse skin. Nat Genet. 2003; 33:416-21.

36. Weng AP, Ferrando AA, Lee W, Morris JP 4th, Silverman LB, Sanchez-Irizarry C, Blacklow SC, Look AT, Aster JC. Activating mutations of NOTCH1 in human T cell acute lymphoblastic leukemia. Science. 2004; 306:269-71.

37. Mansour MR, Linch DC, Foroni L, Goldstone AH, Gale RE. High incidence of Notch-1 mutations in adult patients with T-cell acute lymphoblastic leukemia. Leukemia. 2006; 20:537-39.

38. Meng X, Matlawska-Wasowska K, Girodon F, Mazel T, Willman CL, Atlas S, Chen IM, Harvey RC, Hunger SP, Ness SA, Winter SS, Wilson BS. GSI-I (Z-LLNle-CHO) inhibits $\gamma$-secretase and the proteosome to trigger cell death in precursor-B acute lymphoblastic leukemia. Leukemia. 2011; 25:1135-46.

39. Song H, Boo JH, Kim KH, Kim C, Kim YE, Ahn JH, Jeon GS, Ryu H, Kang DE, Mook-Jung I. Critical role of presenilin-dependent $\gamma$-secretase activity in DNA damageinduced promyelocytic leukemia protein expression and apoptosis. Cell Death Differ. 2013; 20:639-48.

40. Liu B, Wang L, Shen LL, Shen MZ, Guo XD, Wang T, Liang QC, Wang C, Zheng J, Li Y, Jia LT, Zhang H, Gao GD. RNAi-mediated inhibition of presenilin 2 inhibits glioma cell growth and invasion and is involved in the regulation of $\mathrm{Nrg} 1 / \mathrm{ErbB}$ signaling. Neuro-oncol. 2012; 14:994-1006.

41. Bauer K, Gosau M, Reinders J, Oefner P, Reichert TE, Bauer R. Presenilin 1/ $\gamma$-secretase modulates P-cadherin processing and influences cell adhesion in oral squamous cell carcinoma cell lines. Carcinogenesis. 2013; 34:2622-28. 
42. Grigorenko AP, Moliaka YK, Korovaitseva GI, Rogaev EI. Novel class of polytopic proteins with domains associated with putative protease activity. Biochemistry (Mosc). 2002; 67:826-35.

43. Weihofen A, Binns K, Lemberg MK, Ashman K, Martoglio B. Identification of signal peptide peptidase, a presenilintype aspartic protease. Science. 2002; 296:2215-18.

44. Ponting CP, Hutton M, Nyborg A, Baker M, Jansen K, Golde TE. Identification of a novel family of presenilin homologues. Hum Mol Genet. 2002; 11:1037-44.

45. MEROPS database peptidase family A22. http://merops. sanger.ac.uk/cgi-bin/famsum?family=a22

46. Weihofen A, Lemberg MK, Friedmann E, Rueeger H, Schmitz A, Paganetti P, Rovelli G, Martoglio B. Targeting presenilin-type aspartic protease signal peptide peptidase with gamma-secretase inhibitors. J Biol Chem. 2003; 278:16528-33.

47. Moliaka YK, Grigorenko A, Madera D, Rogaev EI. Impas 1 possesses endoproteolytic activity against multipass membrane protein substrate cleaving the presenilin 1 holoprotein. FEBS Lett. 2004; 557:185-92.

48. Grigorenko AP, Moliaka YK, Soto MC, Mello CC, Rogaev EI. The Caenorhabditis elegans IMPAS gene, imp-2, is essential for development and is functionally distinct from related presenilins. Proc Natl Acad Sci USA. 2004; 101:14955-60.

49. Lemberg MK, Bland FA, Weihofen A, Braud VM, Martoglio B. Intramembrane Proteolysis of Signal Peptides: An Essential Step in the Generation of HLA-E Epitopes. Journal of Immunology (Baltimore, Md: 1950). 2001; 167:6441-6.

50. McLauchlan J, Lemberg MK, Hope G, Martoglio B. Intramembrane proteolysis promotes trafficking of hepatitis C virus core protein to lipid droplets. EMBO J. 2002; 21:3980-88.

51. Frömmel C. The apolar surface area of amino acids and its empirical correlation with hydrophobic free energy. J Theor Biol. 1984; 111:247-60.

52. Livingstone $\mathrm{CD}$, Barton GJ. Protein sequence alignments: a strategy for the hierarchical analysis of residue conservation. Comput Appl Biosci. 1993; 9:745-56.

53. http://molbiol.ru/appendix/02_01.html.

54. Rogaev EI, Moliaka YK, Plotnikova OV, Grigorenko AP, Nikishina VA, Veselovsky EM. O2-05-07: Differential Regulation of Proteolytic Activities of Presenilin 1 by Mutational Remodelling. Alzheimer's $\backslash \&$ Dementia. The Journal of the Alzheimer's Association. 2007; 3:S197.

55. Thinakaran G, Borchelt DR, Lee MK, Slunt HH, Spitzer L, Kim G, Ratovitsky T, Davenport F, Nordstedt C, Seeger M, Hardy J, Levey AI, Gandy SE, et al. Endoproteolysis of presenilin 1 and accumulation of processed derivatives in vivo. Neuron. 1996; 17:181-90.
56. Annaert WG, Levesque L, Craessaerts K, Dierinck I, Snellings G, Westaway D, George-Hyslop PS, Cordell B, Fraser P, De Strooper B. Presenilin 1 controls gammasecretase processing of amyloid precursor protein in pregolgi compartments of hippocampal neurons. J Cell Biol. 1999; 147:277-94.

57. Takasugi N, Tomita T, Hayashi I, Tsuruoka M, Niimura M, Takahashi Y, Thinakaran G, Iwatsubo T. The role of presenilin cofactors in the gamma-secretase complex. Nature. 2003; 422:438-41.

58. Luo WJ, Wang H, Li H, Kim BS, Shah S, Lee HJ, Thinakaran G, Kim TW, Yu G, Xu H. PEN-2 and APH-1 coordinately regulate proteolytic processing of presenilin 1 . J Biol Chem. 2003; 278:7850-54.

59. Brunkan AL, Martinez M, Walker ES, Goate AM. Presenilin endoproteolysis is an intramolecular cleavage. Mol Cell Neurosci. 2005; 29:65-73.

60. Campbell WA, Reed ML, Strahle J, Wolfe MS, Xia W. Presenilin endoproteolysis mediated by an aspartyl protease activity pharmacologically distinct from gamma-secretase. J Neurochem. 2003; 85:1563-74.

61. Levitan D, Lee J, Song L, Manning R, Wong G, Parker E, Zhang L. PS1 N- and C-terminal fragments form a complex that functions in APP processing and Notch signaling. Proc Natl Acad Sci USA. 2001; 98:12186-90.

62. Li YM, Xu M, Lai MT, Huang Q, Castro JL, DiMuzioMower J, Harrison T, Lellis C, Nadin A, Neduvelil JG, Register RB, Sardana MK, Shearman MS, et al. Photoactivated gamma-secretase inhibitors directed to the active site covalently label presenilin 1. Nature. 2000; 405:689-94.

63. Mercken M, Takahashi H, Honda T, Sato K, Murayama M, Nakazato Y, Noguchi K, Imahori K, Takashima A. Characterization of human presenilin 1 using N-terminal specific monoclonal antibodies: evidence that Alzheimer mutations affect proteolytic processing. FEBS Lett. 1996; 389:297-303.

64. Murayama O, Murayama M, Honda T, Sun X, Nihonmatsu $\mathrm{N}$, Takashima A. Twenty-nine missense mutations linked with familial Alzheimer's disease alter the processing of presenilin 1. Prog Neuropsychopharmacol Biol Psychiatry. 1999; 23:905-13.

65. Bobrysheva IV, Grigorenko AP, Novosadova EV, Kal'ina NR, Arsenyeva EL, Grivennikov IA, Tarantul VZ, Rogaev EI. Effects of human presenilin 1 isoforms on proliferation and survival of rat pheochromocytoma cell line PC12. Biochemistry (Mosc). 2003; 68:611-17.

66. Wong PC, Zheng H, Chen H, Becher MW, Sirinathsinghji DJ, Trumbauer ME, Chen HY, Price DL, Van der Ploeg LH, Sisodia SS. Presenilin 1 is required for Notch1 and DII1 expression in the paraxial mesoderm. Nature. 1997; 387:288-92. 
67. Schroeter EH, Kisslinger JA, Kopan R. Notch-1 signalling requires ligand-induced proteolytic release of intracellular domain. Nature. 1998; 393:382-86.

68. De Strooper B, Annaert W, Cupers P, Saftig P, Craessaerts K, Mumm JS, Schroeter EH, Schrijvers V, Wolfe MS, Ray WJ, Goate A, Kopan R. A presenilin-1-dependent gamma-secretase-like protease mediates release of Notch intracellular domain. Nature. 1999; 398:518-22.

69. Zhang Z, Nadeau P, Song W, Donoviel D, Yuan M, Bernstein A, Yankner BA. Presenilins are required for gamma-secretase cleavage of beta-APP and transmembrane cleavage of Notch-1. Nat Cell Biol. 2000; 2:463-65.

70. Iso T, Kedes L, Hamamori Y. HES and HERP families: multiple effectors of the Notch signaling pathway. J Cell Physiol. 2003; 194:237-55.

71. Citron M, Oltersdorf T, Haass C, McConlogue L, Hung AY, Seubert P, Vigo-Pelfrey C, Lieberburg I, Selkoe DJ. Mutation of the beta-amyloid precursor protein in familial Alzheimer's disease increases beta-protein production. Nature. 1992; 360:672-74.

72. Cai XD, Golde TE, Younkin SG. Release of excess amyloid beta protein from a mutant amyloid beta protein precursor. Science. 1993; 259:514-16.

73. Belyaev ND, Kellett KA, Beckett C, Makova NZ, Revett TJ, Nalivaeva NN, Hooper NM, Turner AJ. The transcriptionally active amyloid precursor protein (APP) intracellular domain is preferentially produced from the 695 isoform of APP in a \{beta\}-secretase-dependent pathway. J Biol Chem. 2010; 285:41443-54.

74. Lemere CA, Lopera F, Kosik KS, Lendon CL, Ossa J, Saido TC, Yamaguchi H, Ruiz A, Martinez A, Madrigal L, Hincapie L, Arango JC, Anthony DC, et al. The E280A presenilin 1 Alzheimer mutation produces increased A beta 42 deposition and severe cerebellar pathology. Nat Med. 1996; 2:1146-50.

75. Borchelt DR, Thinakaran G, Eckman CB, Lee MK, Davenport F, Ratovitsky T, Prada CM, Kim G, Seekins S, Yager D, Slunt HH, Wang R, Seeger M, et al. Familial Alzheimer's disease-linked presenilin 1 variants elevate Abeta1-42/1-40 ratio in vitro and in vivo. Neuron. 1996; 17:1005-13.

76. De Strooper B, Saftig P, Craessaerts K, Vanderstichele H, Guhde G, Annaert W, Von Figura K, Van Leuven F. Deficiency of presenilin-1 inhibits the normal cleavage of amyloid precursor protein. Nature. 1998; 391:387-90.

77. Weidemann A, Eggert S, Reinhard FB, Vogel M, Paliga K, Baier G, Masters CL, Beyreuther K, Evin G. A novel epsilon-cleavage within the transmembrane domain of the Alzheimer amyloid precursor protein demonstrates homology with Notch processing. Biochemistry. 2002; 41:2825-35.

78. Zhang YW, Wang R, Liu Q, Zhang H, Liao FF, Xu H. Presenilin/gamma-secretase-dependent processing of beta-amyloid precursor protein regulates EGF receptor expression. Proc Natl Acad Sci USA. 2007; 104:10613-18.

79. Okamoto K, Moriishi K, Miyamura T, Matsuura Y. Intramembrane proteolysis and endoplasmic reticulum retention of hepatitis C virus core protein. J Virol. 2004; 78:6370-80.

80. Grakoui A, Wychowski C, Lin C, Feinstone SM, Rice $\mathrm{CM}$. Expression and identification of hepatitis $\mathrm{C}$ virus polyprotein cleavage products. J Virol. 1993; 67:1385-95.

81. McLauchlan J. Properties of the hepatitis C virus core protein: a structural protein that modulates cellular processes. J Viral Hepat. 2000; 7:2-14.

82. Ewald CY, Li C. Understanding the Molecular Basis of Alzheimer's Disease Using a Caenorhabditis Elegans Model System. Brain Structure $\backslash \&$ Function. 2010; 214:263-83. https://doi.org/10.1007/s00429-009-0235-3.

83. Levitan D, Greenwald I. Facilitation of lin-12-mediated signalling by sel-12, a Caenorhabditis elegans S182 Alzheimer's disease gene. Nature. 1995; 377:351-54.

84. Li X, Greenwald I. HOP-1, a Caenorhabditis elegans presenilin, appears to be functionally redundant with SEL12 presenilin and to facilitate LIN-12 and GLP-1 signaling. Proc Natl Acad Sci USA. 1997; 94:12204-09.

85. Saura CA, Choi SY, Beglopoulos V, Malkani S, Zhang D, Shankaranarayana Rao BS, Chattarji S, Kelleher RJ 3rd, Kandel ER, Duff K, Kirkwood A, Shen J. Loss of presenilin function causes impairments of memory and synaptic plasticity followed by age-dependent neurodegeneration. Neuron. 2004; 42:23-36.

86. Quiroz YT, Schultz AP, Chen K, Protas HD, Brickhouse M, Fleisher AS, Langbaum JB, Thiyyagura P, Fagan AM, Shah AR, Muniz M, Arboleda-Velasquez JF, Munoz C, et al. Brain Imaging and Blood Biomarker Abnormalities in Children With Autosomal Dominant Alzheimer Disease: A Cross-Sectional Study. JAMA Neurol. 2015; 72:912-19.

87. Yu G, Chen F, Nishimura M, Steiner H, Tandon A, Kawarai T, Arawaka S, Supala A, Song YQ, Rogaeva E, Holmes E, Zhang DM, Milman P, et al. Mutation of conserved aspartates affect maturation of presenilin 1 and presenilin 2 complexes. Acta Neurol Scand Suppl. 2000; 176:6-11.

88. Berezovska O, Jack C, McLean P, Aster JC, Hicks C, Xia W, Wolfe MS, Kimberly WT, Weinmaster G, Selkoe DJ, Hyman BT. Aspartate mutations in presenilin and gammasecretase inhibitors both impair notch1 proteolysis and nuclear translocation with relative preservation of notch1 signaling. J Neurochem. 2000; 75:583-93.

89. Xia X, Wang P, Sun X, Soriano S, Shum WK, Yamaguchi $\mathrm{H}$, Trumbauer ME, Takashima A, Koo EH, Zheng H. The aspartate-257 of presenilin 1 is indispensable for mouse development and production of beta-amyloid peptides 
through beta-catenin-independent mechanisms. Proc Natl Acad Sci USA. 2002; 99:8760-65.

90. Arduengo PM, Appleberry OK, Chuang P, L'Hernault SW. The presenilin protein family member SPE-4 localizes to an ER/Golgi derived organelle and is required for proper cytoplasmic partitioning during Caenorhabditis elegans spermatogenesis. J Cell Sci. 1998; 111:3645-54.

91. Guo Y, Livne-Bar I, Zhou L, Boulianne GL. Drosophila presenilin is required for neuronal differentiation and affects notch subcellular localization and signaling. J Neurosci. 1999; 19:8435-42.

92. Tomita T, Watabiki T, Takikawa R, Morohashi Y, Takasugi N, Kopan R, De Strooper B, Iwatsubo T. The first proline of PALP motif at the $\mathrm{C}$ terminus of presenilins is obligatory for stabilization, complex formation, and gamma-secretase activities of presenilins. J Biol Chem. 2001; 276:33273-81.

93. Wang J, Beher D, Nyborg AC, Shearman MS, Golde TE, Goate A. C-terminal PAL motif of presenilin and presenilin homologues required for normal active site conformation. J Neurochem. 2006; 96:218-27.

94. Sato C, Takagi S, Tomita T, Iwatsubo T. The C-terminal PAL motif and transmembrane domain 9 of presenilin 1 are involved in the formation of the catalytic pore of the gamma-secretase. J Neurosci. 2008; 28:6264-71.

95. Rogaeva EA, Fafel KC, Song YQ, Medeiros H, Sato C, Liang Y, Richard E, Rogaev EI, Frommelt P, Sadovnick AD, Meschino W, Rockwood K, Boss MA, et al. Screening for PS1 mutations in a referral-based series of AD cases: 21 novel mutations. Neurology. 2001; 57:621-25.

96. Heilig EA, Xia W, Shen J, Kelleher RJ 3rd. A presenilin-1 mutation identified in familial Alzheimer disease with cotton wool plaques causes a nearly complete loss of gamma-secretase activity. J Biol Chem. 2010; 285:22350-59.
97. Ishikawa A, Piao YS, Miyashita A, Kuwano R, Onodera O, Ohtake H, Suzuki M, Nishizawa M, Takahashi H. A mutant PSEN1 causes dementia with Lewy bodies and variant Alzheimer's disease. Ann Neurol. 2005; 57:429-34.

98. Kaneko H, Kakita A, Kasuga K, Nozaki H, Ishikawa A, Miyashita A, Kuwano R, Ito G, Iwatsubo T, Takahashi H, Nishizawa M, Onodera O, Sisodia SS, Ikeuchi T. Enhanced accumulation of phosphorylated alpha-synuclein and elevated beta-amyloid 42/40 ratio caused by expression of the presenilin-1 deltaT440 mutant associated with familial Lewy body disease and variant Alzheimer's disease. J Neurosci. 2007; 27:13092-97.

99. Pérez-Revuelta BI, Fukumori A, Lammich S, Yamasaki A, Haass C, Steiner H. Requirement for small side chain residues within the GxGD-motif of presenilin for gamma-secretase substrate cleavage. J Neurochem. 2010; 112:940-50.

100. http://browser.1000genomes.org.

101. Smirnov A, Trupp A, Henkel AW, Bloch E, Reulbach U, Lewczuk P, Riggert J, Kornhuber J, Wiltfang J. Differential processing and secretion of Abeta peptides and sAPPalpha in human platelets is regulated by thrombin and prostaglandine 2. Neurobiol Aging. 2009; 30:1552-62.

102. Wiltfang J, Smirnov A, Schnierstein B, Kelemen G, Matthies U, Klafki HW, Staufenbiel M, Hüther G, Rüther E, Kornhuber J. Improved electrophoretic separation and immunoblotting of beta-amyloid (A beta) peptides 1-40, 1-42, and 1-43. Electrophoresis. 1997; 18:527-32.

103. Bibl M, Esselmann H, Otto M, Lewczuk P, Cepek L, Rüther E, Kornhuber J, Wiltfang J. Cerebrospinal fluid amyloid beta peptide patterns in Alzheimer's disease patients and nondemented controls depend on sample pretreatment: indication of carrier-mediated epitope masking of amyloid beta peptides. Electrophoresis. 2004; 25:2912-18.

104. Brenner S. The genetics of Caenorhabditis elegans. Genetics. 1974; 77:71-94. 